
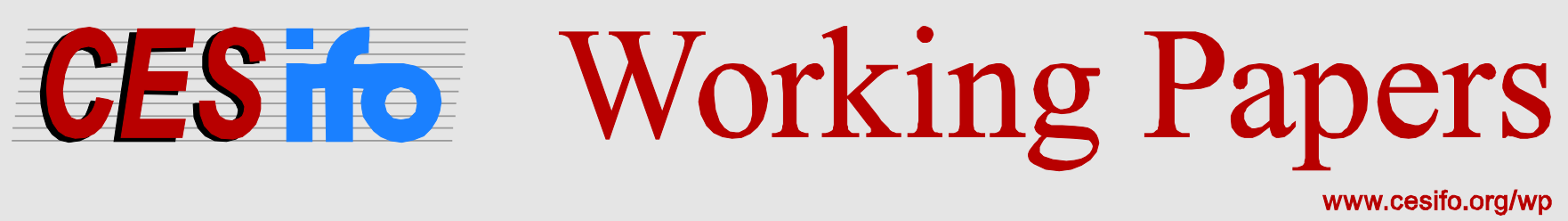

\title{
No Place Like Home? Graduate Migration in Germany
}

\author{
Tina Haussen \\ Silke Uebelmesser
}
CESIFO WORKING PAPER NO. 5524
CATEGORY 1: PUBLIC FINANCE
SEPTEMBER 2015

An electronic version of the paper may be downloaded

- from the SSRN website:

- from the RePEc website:

- from the CESifo website:

wWw.SSRN.com

Www.RePEc.org

www.CESifo-group.org/wp 


\title{
No Place Like Home? Graduate Migration in Germany
}

\begin{abstract}
We empirically analyze sub-national migration of graduates in Germany and its determinants. Based on a longitudinal, representative survey-based dataset of students who graduated in the academic year 2004/2005, we observe the transition to the labor market and previous and subsequent migration patterns. We find that, five years after graduation, about $60 \%$ of the graduates are employed in the university state either because they have stayed or returned. Whether or not graduates migrate largely depends on previous migration, job search characteristics and the states' economic conditions. This results in an unbalanced migration of graduates between German states. From a public policy perspective, our analysis provides some rational for correction mechanisms.
\end{abstract}

JEL-Code: I280, H720, H750, J610.

Keywords: graduate migration, higher education funding, longitudinal graduate survey, job changes.

\author{
Tina Haussen \\ University of Jena \\ Carl-Zeiss-Str. 3 \\ Germany-07743 Jena \\ tina.haussen@uni-jena.de
}

\author{
Silke Uebelmesser \\ University of Jena \\ Carl-Zeiss-Str. 3 \\ Germany-07743 Jena \\ silke.uebelmesser@uni-jena.de
}

\section{August 31, 2015}

The authors thank participants at the EEA in Mannheim, the IIPF in Dublin, the CEMIR Junior Economist Workshop on Migration Research in Munich and the JERW Seminar in Jena as well as Alexia Gaudeul for many helpful suggestions and comments. 


\section{Introduction}

In Germany, tertiary education is mainly publicly financed. In 2010, overall expenditures for German universities amounted to 32 bn Euro. A substantial proportion of the funds $(65.0 \%)$ is covered by the states ("Länder") whereas the federal government bears $18.7 \%$ of the costs and private contributions amount to 16.3\% (Dohmen and Krempkow 2014). As for the public financing part, higher education involves an implicit loan from the government to the students, which they are supposed to repay after graduation. As tertiary educated individuals earn, on average, comparatively high wages, they can also be expected to pay high taxes (Gérard and Uebelmesser 2014). However, university graduates are not only highly educated but also highly mobile (Faggian and McCann 2009, Venhorst et al. 2011, Krabel and Flöther 2012). The public benefits may then not fully occur in the state which has financed tertiary education. The aim of this paper is, first, to descriptively analyze migration of graduates between German states and, second, to empirically study possible determinants of these migration patterns in order to assess the consequences for public policy.

For this, we combine two strands of literature. First, we consider the literature that deals with the determinants of graduate migration. Focusing on the first job after graduation, Krabel and Flöther (2012) use the German graduate survey KOAB. They find that about $61 \%$ of the graduates leave the university region for their first employment and $38 \%$ migrate even to another state. According to their results, the decision to migrate is positively determined by previous migration. When using personal networks for job search, however, graduates are more likely to stay in the university region. Migration is also less likely to occur with strong family ties and children. In an analysis of the federal state of Bavaria, Falk and Kratz (2009) provide evidence that on average $75 \%$ of Bavarian graduates have their first employment in Bavaria. This, however, differs strongly across fields of study. Whereas only $10 \%$ of graduates in machine and electrical engineering leave Bavaria for work reasons, this is true for more than one third of graduates in business administration. Lenz et al. (2010) use survey data on graduates in Saxony and find that about $40 \%$ migrate to another state after graduation for work reasons. A large share of this group, however, had migrated to Saxony before in order to study there.

In addition, the medium- and long-term migration patterns for employment reasons have received some attention in the literature. Making use of the annual household survey of the German Socio-Economic Panel, Busch and Weigert (2010) use information about individuals who graduated between 1984 and 2004. Slightly more than $70 \%$ of the graduates in their sample stayed in the state where they finished studying. Applying a parametric hazard model, Busch and Weigert (2010) show that partner, children and a degree from a university of applied sciences ("Fachhochschule") make it more likely to stay in the university state. Marinelli (2013) analyzes migration of graduates in Italy within three years after graduation. She distinguishes between three groups of graduates, stayers, onward migrants and return migrants, and finds that onward migrants are more likely to move to richer and more innovative regions compared to return migrants.

Second, there are close links to the literature that deals with the consequences of graduate migration for the financing of higher education. Mobile graduates may benefit from tertiary education funded by one state but may not pay for their education in terms of income taxes after graduation if they move to another state or abroad (Krieger and Lange 2010). 
Migration of graduates may cause spillovers that give rise to underinvestment, i.e., states have an incentive to provide a suboptimally low level of higher education (Justman and Thisse 2000, Del Rey 2001).

This paper extends the literature on graduate migration in several ways: First, by using data from a representative and longitudinal graduate survey in Germany which provides information about the work history for the first five years after graduation, we can analyze the sub-national migration patterns of graduates in Germany in more detail. The five year observation period allows us to explicitly take into account that many graduates have more than one job after graduation and that a non negligible share of them is highly mobile. Second, given the interest in the consequences for public policy of possibly unbalanced migration across states, a different complementary perspective is added to the previous research. Knowledge about the determinants of graduate migration is crucial to policy makers in order to develop strategies on how to keep or attract the highly skilled (Venhorst et al. 2011) and to understand the potential need for policies that deal with the fiscal consequences of high-skilled migration.

We show that many graduates are mobile job-wise and across states and that migration flows are not balanced. Interesting patterns emerge with respect to onward and return migration when controlling for previous migration, individual characteristics of graduates and aspects related to their studies, the labour market and the states' economic conditions. Previous migration makes it more likely to observe out-migration, while the probability of staying is higher for graduates with closer ties to that state. Additionally, graduate migration strongly depends on the states' economic conditions.

The remainder of the paper is structured as follows. In Section 2, we study job change behavior and migration patterns. In Section 3, the possible determinants of graduate migration are discussed. The empirical strategy and our results are given in Sections 4 and 5. Section 6 concludes.

\section{Migration of graduates in Germany}

\subsection{The data}

We use data collected by the DZHW ('Deutsches Zentrum für Hochschul- und Wissenschaftsforschung', Grotheer et al. 2012) on students who graduated from higher education institutions in Germany in the academic year 2004/05. The graduate survey is representative and longitudinal consisting of two parts - one part in 2006 and one part at the end of the year 2010. For the first part of the survey, about one year after graduation, individuals are asked about their studies, their qualifications and competencies and about their transition from university to the labor market. Additionally, the survey provides information on socio-economic characteristics such as gender, age and marital status. Most important for the analysis here, we observe whether graduates migrated across federal states for studying or for job reasons. The focus of the second part of the survey five years after graduation is on the employment history of the graduates, in particular, the type, duration and sector of the occupation(s) as well as their location. From the latter information, we can derive the graduates' migration patterns. 6,495 graduates took part 
in both parts of the survey with 4,740 answering all our questions of interest. ${ }^{1}$

The graduate survey is well suited for our research purpose for several reasons. First, it provides detailed information on the location of the graduates at different stages of their life: when acquiring their university entrance certificate, when graduating, when having their first employment after graduation, and for every further employment within the first five years after graduation. Second, geographical information is available at the state level. Even though in some other studies graduate migration is analyzed at the regional level (see, e.g., Faggian and McCann 2009, Krabel and Flöther 2012), the state-level aggregation is very suitable for our analysis. This follows from the fact that in Germany, the states are largely responsible for providing and financing higher education. Finally, the survey contains many questions capturing different individual, study-related and job-related aspects which can be used as control variables.

A potential drawback of the five-year observation period is that the survey data of the very recent cohort cannot be used. ${ }^{2}$ The graduate cohort of 2004/05 has, however, one important advantage compared to the newer cohort: At the time of this cohort's studies, no tuition fees were charged. After an episode between 2006 and 2014 where some states charged moderate fees, there are now once again no regular tuition fees in Germany. This allows drawing conclusions from the results of this analysis about graduate migration patterns also for today.

In order to provide a more detailed picture of migration of German graduates, we proceed as follows: In a first step, we investigate the migration patterns between school and university as well as between university and the first employment. In a second step, we focus on the employment-related migration within five years after graduation. Finally, we study the frequency of job changes and whether these changes involve inter-state migration. ${ }^{3}$

\subsection{Migration patterns: School, university and first job}

Table 1 displays the shares of mobile and immobile graduates for the transitions from school to university and from university to the first employment, respectively. All data are calculated relative to the state of graduation ('university state'). On average, $30.2 \%$ of the graduates left the state in which they obtained their university entrance certificate ('school state') for studying. More than half of all students who graduated in Bremen, Hamburg and Rhineland Palatinate did not attend school there. Conversely, more than $70 \%$ of all graduates in Northrhine Westphalia, Bavaria, Hesse and Baden-Württemberg also attended school in their university states. Whether a state hosts a large share of students from other states is an important variable to consider as there is empirical evidence that the propensity to migrate is higher for those graduates who have migrated before (see, e.g., Parey and Waldinger 2011).

1 Given the non-responses, the DZHW attributes sample weights to each graduate in the final dataset, such that the panel is representative for East and West Germany with respect to gender, degree, field of study and state. The analyses in this paper are performed using these sample weights.

2 The answers to the second questionnaire (five years after graduation) of the most recent surveyed graduate cohort of 2009 have not yet been released.

${ }^{3}$ For a study focusing on Thuringia as university state, see Haussen et al. (2014). 
Table 1: Graduate migration: School, university, first job

\begin{tabular}{|c|c|c|c|c|}
\hline \multirow[t]{2}{*}{ University state } & \multicolumn{2}{|c|}{ School $\rightarrow$ University } & \multicolumn{2}{|c|}{ University $\rightarrow$ First job } \\
\hline & Stayed & In-Migration & Stayed & Out-Migration \\
\hline Baden-Württemberg & 72.6 & 27.5 & 69.3 & 30.7 \\
\hline Bavaria & 80.5 & 19.5 & 78.8 & 21.2 \\
\hline Berlin & 52.7 & 47.3 & 63.1 & 36.9 \\
\hline Brandenburg & 53.3 & 46.7 & 36.8 & 63.3 \\
\hline Bremen & 18.1 & 81.9 & 33.8 & 66.2 \\
\hline Hamburg & 45.2 & 54.8 & 62.6 & 37.4 \\
\hline Hesse & 73.0 & 27.0 & 69.9 & 30.1 \\
\hline Lower Saxony & 65.5 & 34.5 & 56.4 & 43.6 \\
\hline Mecklenburg Western Pomerania & 53.0 & 47.0 & 47.5 & 52.5 \\
\hline Northrhine Westphalia & 82.5 & 17.6 & 75.1 & 24.9 \\
\hline Rhineland Palatinate & 49.2 & 50.8 & 54.3 & 45.7 \\
\hline Saarland & 67.4 & 32.6 & 72.8 & 27.3 \\
\hline Saxony & 69.4 & 30.6 & 59.5 & 40.5 \\
\hline Saxony-Anhalt & 65.6 & 34.4 & 49.8 & 50.2 \\
\hline Schleswig-Holstein & 62.0 & 38.1 & 67.4 & 32.6 \\
\hline Thuringia & 62.3 & 37.7 & 40.9 & 59.2 \\
\hline Average & 69.9 & 30.2 & 65.2 & 34.8 \\
\hline
\end{tabular}

Note: $4.7 \%$ of all graduates moved abroad for their first job.

Source: DZHW graduate survey, own computations.

Let us, next, consider migration of graduates when entering the labor market. The state of the first employment is identified by the first regular job. Internships and casual jobs are ignored. On average, $34.8 \%$ of all graduates leave the university state ${ }^{4}$, whereas roughly $65 \%$ start to work in the state in which they graduated. More than half of all graduates leave Bremen and the East German states Brandenburg, Thuringia, Mecklenburg Western Pomerania and Saxony-Anhalt. On the contrary, not even one out of four graduates leaves Bavaria or Northrhine Westphalia, respectively.

Gross migration flows as in Table 1 do not show, however, in which state the graduates had finished school and where they went for work reasons. To assess whether migration flows are balanced or unbalanced for individual states, both inflows and outflows have to be taken into account. Figure 1 displays net migration for the transitions from school to university (Panel a) and from university to the first employment (Panel b). Net migration represents an indicator of a state's attractiveness - either as a place to study or as a place to work. The green color shades illustrate a net gain. The orange color shades depict a net loss.

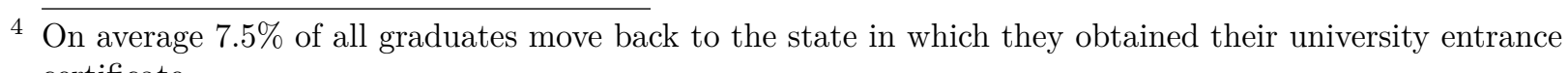
certificate. 


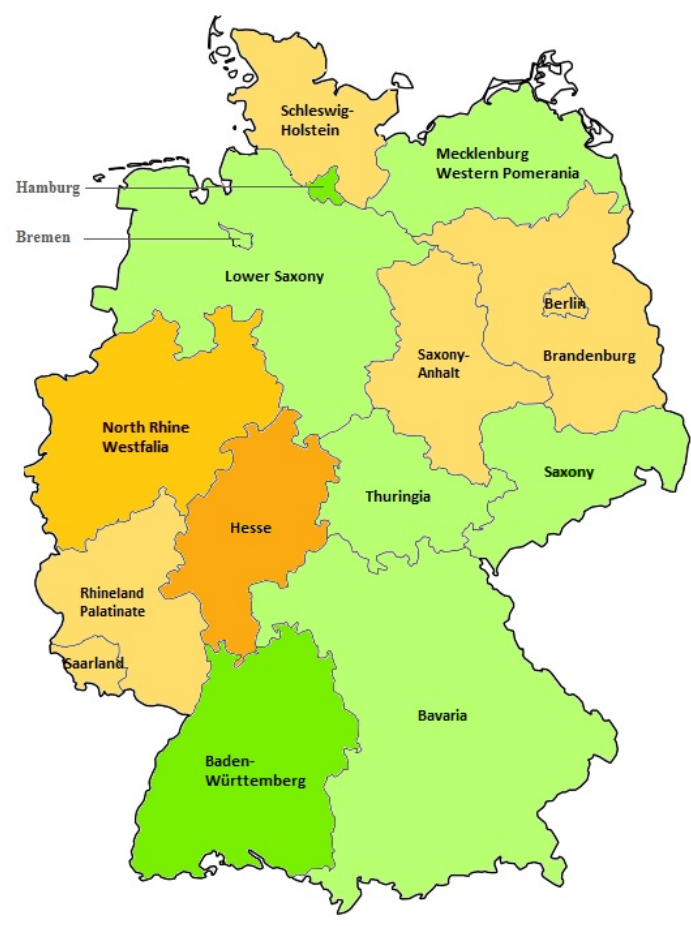

(a) School $\rightarrow$ University

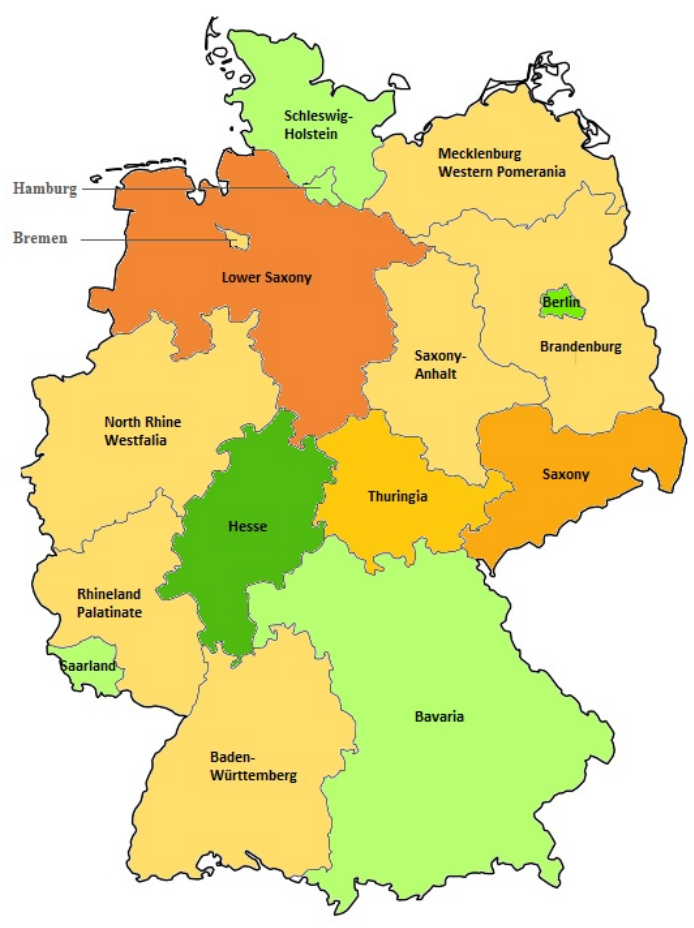

(b) University $\rightarrow$ First job

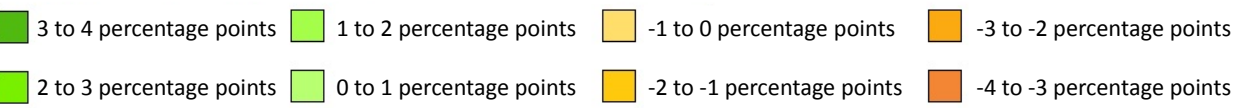

Figure 1: Migration of graduates

Note: In panel (a), we subtract the share of high school graduates in one state relative to all high school graduates from the share of university graduates in that state relative to all university graduates. In panel (b), the same methodology is applied to the share of graduates and the share of graduates with their first job, respectively.

Baden-Württemberg and Hamburg but also Lower Saxony, Bavaria, Bremen and the East German states Thuringia, Saxony and Mecklenburg Western Pomerania seem to be preferred as places to study while especially for Hesse and Northrhine Westphalia, a substantial loss is reported. $7.7 \%$ of all graduates, e.g., have acquired their university entrance examination in Saxony whereas the share of Saxon graduates on all graduates is 8.6\%. This means a plus of 0.9 percentage points. For Hesse, on the contrary, a share of high school graduates of $7.0 \%$ and a share of university graduates of $4.8 \%$ imply a minus of 2.2 percentage points. This picture changes significantly when net migration of graduates for their first job is considered. Lower Saxony, Baden-Württemberg, Bremen, Saarland, Thuringia, Saxony and Mecklenburg Western Pomerania face a net loss of high skilled graduates, while Hesse, Berlin, Saarland and Schleswig-Holstein gain. 


\subsection{Migration patterns: University and job(s) five years after graduation}

Focusing only on the first job after graduation neglects that individuals often have more than one job in the first years after graduation. This may lead to a biased picture of graduate migration as it may well be that graduates choose a first (temporary) job in one state but move for subsequent jobs. Given the focus of the analysis on sub-national migration patterns of graduates, it is necessary to know whether graduates have more than one job and whether job changes also mean inter-state migration.

With information on all jobs within the first years after graduation and the related migration, we follow Marinelli (2013) and distinguish three groups of graduates:

1. Stayers: Those who have not left the university state within the first five years after graduation.

2. Onward migrants: Those who, five years after graduation, are working in a state different to the university state.

3. Return migrants: Those who had left the university state for work reasons but moved back to this state within five years after graduation. ${ }^{5}$

Table 2: Graduate migration: University, job(s) five years after graduation

\begin{tabular}{|c|c|c|c|c|}
\hline \multirow[t]{2}{*}{ University state } & \multirow[t]{2}{*}{ Stayer } & \multicolumn{2}{|c|}{ Mobile graduates } & \multirow{2}{*}{$\begin{array}{c}\text { Stayer }+ \\
\text { Return migrants }\end{array}$} \\
\hline & & Onward migrants & Return migrants & \\
\hline Baden-Württemberg & 50.3 & 37.8 & 11.9 & 62.2 \\
\hline Bavaria & 66.0 & 25.7 & 8.4 & 74.4 \\
\hline Berlin & 49.4 & 36.6 & 14.0 & 63.4 \\
\hline Brandenburg & 22.5 & 70.4 & 7.1 & 29.6 \\
\hline Bremen & 19.0 & 73.6 & 7.5 & 26.5 \\
\hline Hamburg & 47.8 & 40.3 & 11.9 & 59.7 \\
\hline Hesse & 59.3 & 33.1 & 7.6 & 66.9 \\
\hline Lower Saxony & 38.9 & 50.7 & 10.4 & 49.3 \\
\hline Mecklenburg West. Pom. & 29.4 & 64.5 & 6.1 & 35.5 \\
\hline Northrhine Westphalia & 62.2 & 29.2 & 8.7 & 70.9 \\
\hline Rhineland Palatinate & 37.6 & 56.0 & 6.4 & 44.0 \\
\hline Saarland & 50.6 & 41.3 & 8.1 & 58.7 \\
\hline Saxony & 45.7 & 46.0 & 8.3 & 54.0 \\
\hline Saxony-Anhalt & 32.9 & 58.1 & 9.1 & 42.0 \\
\hline Schleswig-Holstein & 49.0 & 42.2 & 8.7 & 57.7 \\
\hline Thuringia & 26.0 & 67.1 & 6.9 & 32.9 \\
\hline Average & 50.0 & 40.8 & 9.2 & 59.2 \\
\hline
\end{tabular}

Source: DZHW graduate survey, own computations.

Table 2 displays the shares of graduates of each group by university state. After five years, $59.2 \%$ of graduates live in the state where they completed their studies $-50.0 \%$ of

5 Note that the definition in Marinelli (2013) is slightly different: Return migrants are those who have left their region of study to go back to their home region. 
them stayed and $9.2 \%^{6}$ returned. However, there are important differences across states. Whereas more than $60 \%$ of all graduates in Bavaria and Northrhine Westphalia found a job in their university state and stayed there, this is true for less than $30 \%$ of graduates in Bremen and the East German states Brandenburg, Thuringia and Mecklenburg Western Pomerania. Not surprisingly, these are the same states that have the largest shares of onward migrants.

When considering the last job within the first five years after graduation, the imbalance in net migration between German states is even more pronounced than the one we found for the first job (cf. Figure 2). The net gain from graduate migration increases in the federal city states Hamburg and Berlin. On the contrary, Baden-Württemberg and Mecklenburg Western Pomerania face a larger net loss. There is only one state switching position: while Schleswig-Holstein faces a small net gain for the first job, in the medium run, however, Schleswig-Holstein suffers from a small net loss of graduates. Overall, all East German states (except Berlin) face a net outflow of graduates.
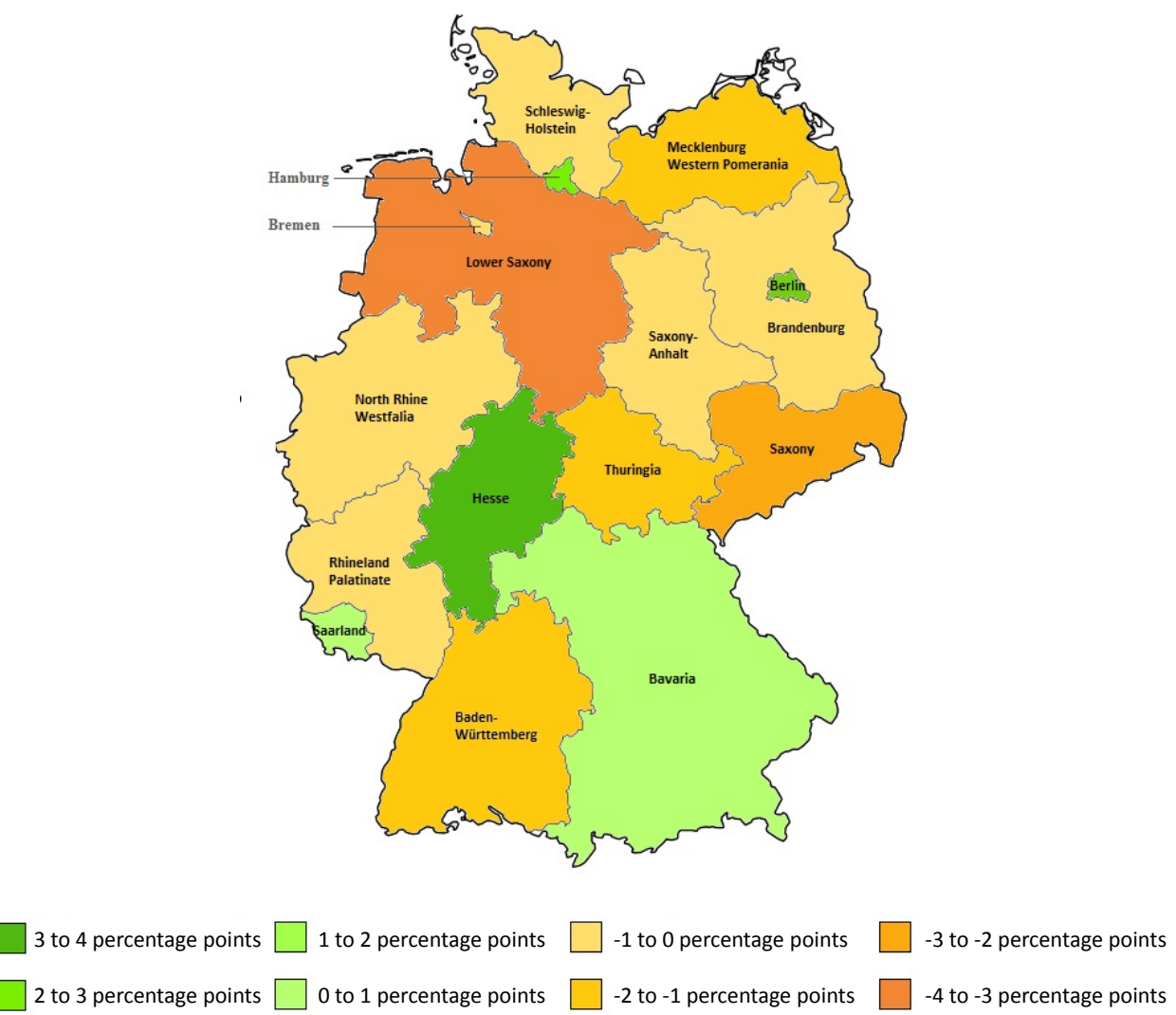

Figure 2: Migration of graduates (University $\rightarrow$ Job five years after graduation) Note: See Figure 1 for the methodology applied.

${ }^{6}$ For approximately two thirds of them the state in which they studied is also the state in which they obtained their high school degree. 


\subsection{Job change frequency and the importance of inter-state migration}

For an assessment of the general dynamics, not only the first job and the last job five years after graduation are of interest. Also the job changes during that period, i.e. their frequency and their geographic distribution, deserve a more detailed study. Figure 3a illustrates the share of graduates with one or more jobs within the first five years after graduation, with an average of 2.7 jobs in that five-year period. ${ }^{7}$ Roughly $15.9 \%$ only have one job - mostly with an unlimited work contract. However, more than one third of all graduates have two, while $26.8 \%$ have three and $13.9 \%$ have four jobs. Less than $10 \%$ of graduates have five or more jobs.

As to inter-state migration, Figure 3a shows that among those graduates with only one job during the first five years after graduation (15.9\% of all graduates), roughly $62 \%$ stay in the university state while $38 \%$ migrate to another state or abroad. Of the graduates with two jobs, almost $52 \%$ stay for both jobs in the state in which they graduated. $41.7 \%$ are onward migrants and roughly $7 \%$ are return migrants, i.e., they leave the university state for their first job but return there for their second job. The relative proportion of stayers decreases for those with three, four or five jobs, whereas the share of onward migrants and return migrants increases.

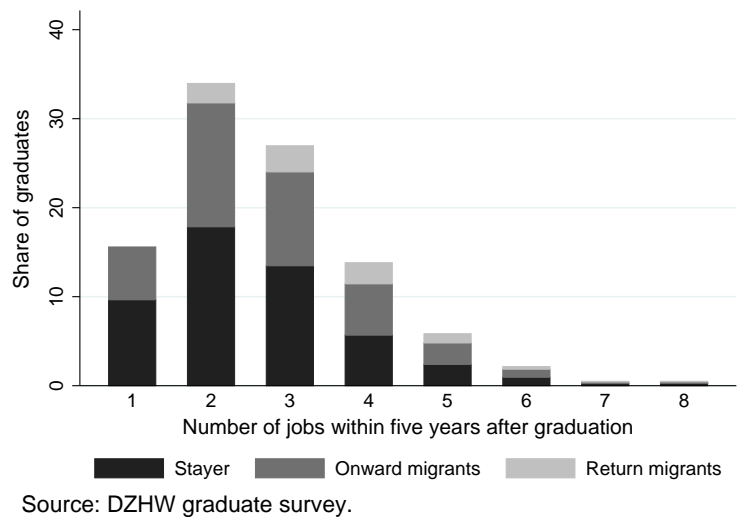

(a) Graduates by number of jobs and migration type

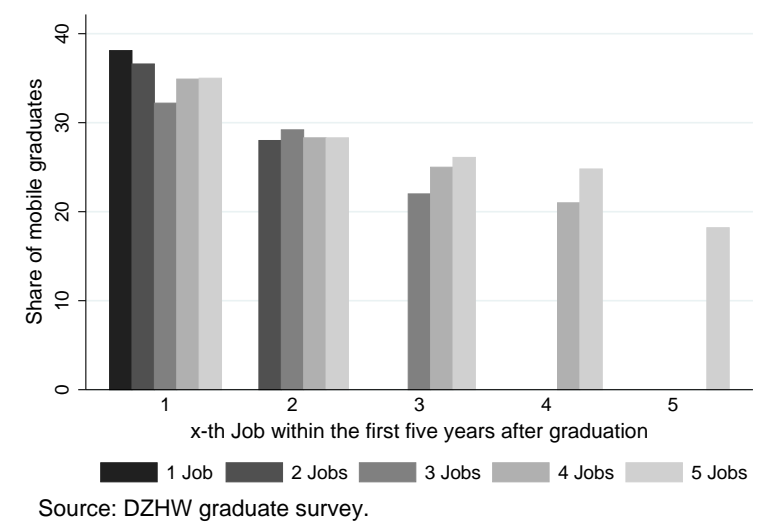

(b) Graduates by number of jobs and migration instances

Figure 3: Job change and migration pattern

In order to assess in more detail the migration patterns, we study the relation between job changes and changes of the state. According to Figure 3b, more than $30 \%$ leave the university state for their first job. This holds for graduates with one, two and up to five jobs during the first five years after graduation. Also for a second, third or fourth change of jobs, more than $20 \%$ leave the state of their previous job(s).

Summing up, several regularities can be observed: First, a considerable share of graduates has migrated between German states at any time between end of school and five years

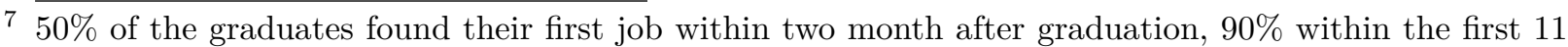
month. These shares are relative similar to those found by Krabel and Flöther (2012) who observe graduates' first employment situation twelve to twenty-four month after graduation. In our sample, however, $98.1 \%$ of all graduates found a (first) job within five years after graduation. 
after graduation. Second, the majority of graduates has more than one job within the first five years after graduation with a substantial number of job changes involving interstate migration. Whereas a significant share of graduates leaves the university state for employment reasons we also observe a non-negligible share of graduates returning to the university state at some point in time within five years. Third, the resulting net migration is not balanced. Some states are net winners while others are net losers. In the following, we use the information on the migration patterns in order to empirically estimate the determinants of the graduates' migration decision. We not only consider migration for the first job after graduation but also for the job five years after graduation. In order to account for unobserved individual characteristics which may affect the migration propensity, we use information on the individuals' previous migration, in particular, information on migration between school and university or during studies.

\section{Determinants of migration}

The reviewed literature in Section 1 guides our choice of the independent variables. Table 3 provides summary statistics disaggregated by migration group, i.e. whether a graduate stayed or migrated for the first job and whether he stayed, migrated or migrated but returned within five years after graduation. ${ }^{8}$ We expect the likelihood of graduates moving between states to be related to previous migration, individual characteristics of the graduates as well as aspects related to their studies, the labor market and the states' economic conditions.

Migration experience: There is evidence in the economic literature that the propensity to migrate is higher for those individuals who have migrated before (see, e.g., Parey and Waldinger 2011). In order to test this, we control for whether graduates already migrated for studying reasons and whether they went abroad during their studies. For the analysis of migration in the first five years after graduation, we additionally include whether the state of the first job equals the school state (the state of the university entrance certificate) and we control for the number of jobs after graduation. A first job in the school state may lower the likelihood to migrate due to stronger ties to this state while more jobs may also imply more migration. The summary statistics in Table 3 provide some indications in support of these hypotheses.

Study characteristics: The German system of higher education consists of universities and universities of applied sciences ("Fachhochschulen"). Generally spoken, universities are more theoretically oriented whereas universities of applied sciences are more oriented towards the practical use of theoretical knowledge and maintain closer contact with the (regional) labor market (Jaeger and Kopper 2014). We would, therefore, expect graduates from universities to be relatively more mobile (Falk and Kratz 2009). Additionally, we separately account for teachers' state examination as the labor market for teachers is very much confined to a specific state. In our sample, a significantly larger share of university graduates is mobile in the short and medium run whereas teachers more often belong to the group of stayers (see Table 3). We further control for the exam grade. Worse graduates may need to search longer for a job and may need to migrate; analogously, better graduates may be able to realize their potential better elsewhere. Given the possibly geographically

\footnotetext{
8 Summary statistics of all variables used in the empirical analysis are given in Table A.1.
} 
differing relative demand and supply for different qualifications, we also take the fields of study into account. An insufficient demand may make migration more necessary than a rather balanced situation. Based on the summary statistics in Table 3, one may expect graduates from medicine, agriculture and engineering to be more mobile than graduates from language and natural science studies.

Socio-economic characteristics: For the analysis of migration for the first job as well as for any subsequent employment, we control for individual characteristics such as gender, age, marital status, children and whether the graduate completed vocational training before studying. These variables can be expected to be closely related to migration costs, especially those about the private environment.

Characteristics of the university state: The German federal states differ in their economic conditions which may affect the migration decision of graduates - either as push or pull factors. To control for this, on the one hand, we use the university states' GDP growth rate and unemployment rate in the year of graduation. Assuming individuals to aim at maximizing individual utility, one would expect out-migration from states with less favorable economic conditions, i.e. lower productivity growth and a higher unemployment rate. To capture the structure of the labor market, we include the share of large firms (> 250 employees) in the university state among all large firms in Germany. The positive link between firm size and wages has often been proven in the economic literature (see, e.g., Troske 1999, Gibson and Stillman 2009). Moreover, we include a control for the share of the population living in cities with more than 100,000 inhabitants in the university state. ${ }^{9}$ Dense, urban regions have found to be characterized by a large share of high-skilled workers because of positive sorting resulting in an increase in average productivity. This, in turn, may make human capital accumulate more quickly in urban areas (see, e.g., Venables 2010, Glaeser and Resseger 2010). ${ }^{10}$ All variables above are calculated relative to the respective German average for the year 2005. To capture possible (other) East-West differences, we moreover include a dummy for East German university states. The summary statistics in Table 3 seem to largely confirm our hypotheses.

Job search characteristics (first job): Based on the results of Krabel and Flöther (2012), we include variables that capture job search characteristics. These encompass whether a graduate found the first job by previous employment experience or with the help of friends or relatives. We also control for the number applications the graduate sent before finding a first employment and whether he faced difficulties in finding a job because too few appropriate jobs were offered, most jobs were too far away, salary expectations were not met or because of problems in balancing family and work. From our summary statistics in Table 3, we expect graduates who did not have to search for their first job to be less likely to migrate.

Characteristics of the first job: For the analysis of migration in the first five years after graduation, we control for characteristics of the first job. These encompass the wage, whether the graduate was employed, self-employed or a civil servant, whether the first employment contract was temporary or unlimited and whether the graduate self-assessed that the job level was adequate with respect to the own level of education. The need to

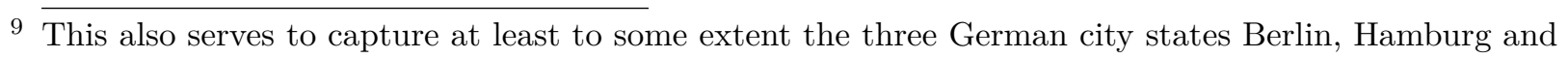
Bremen.

${ }^{10}$ Due to multicollinearity, we cannot include a control for the states' population size. 
search for a new job (and with this the potential need to migrate) is likely to be larger if the first job is only temporary. Moreover, we make use of information on the sector of the first job as different sectors might be differently geographically concentrated leading to different migration patterns.

Reasons for job change: Self-assessed reasons regarding the graduate's last job change in our period of observation are also included. Table 3 indicates that job changes to improve the chances of advancement, the qualification matching or the salary or to reduce the distance from their partner are all associated with more migration.

Table 3: Summary statistics by migration taxonomy

\begin{tabular}{|c|c|c|c|c|c|}
\hline & \multicolumn{2}{|c|}{ University $\rightarrow$ First Job } & \multicolumn{3}{|c|}{$\begin{array}{c}\text { University } \rightarrow \text { Job } \\
\text { (five years after graduation) }\end{array}$} \\
\hline & Stayer & Migrant & Stayer & $\begin{array}{l}\text { Onward } \\
\text { migrant }\end{array}$ & $\begin{array}{l}\text { Return } \\
\text { migrant }\end{array}$ \\
\hline $\begin{array}{l}\text { Mobility } \\
\text { Migration from school to university }{ }^{\circ} \\
\text { International migration during studies }^{\circ} \\
\text { School state }=\text { state of the first job }{ }^{\circ} \\
\text { Number of jobs within five years after graduation }\end{array}$ & $\begin{array}{l}0.19 \\
0.30\end{array}$ & $\begin{array}{l}0.52^{* * *} \\
0.46^{* * *}\end{array}$ & $\begin{array}{l}0.16 \\
0.27 \\
0.84 \\
2.46\end{array}$ & $\begin{array}{l}0.49^{* * *} \\
0.45^{* * *} \\
0.37^{* * *} \\
2.77^{* * *}\end{array}$ & $\begin{array}{l}0.29^{* * *} \\
0.41^{* * *} \\
0.37^{* * *} \\
3.56^{* * *}\end{array}$ \\
\hline $\begin{array}{l}\text { Study characteristics } \\
\text { Exam grade } \\
\text { University }^{\circ}(\mathrm{R}) \\
\text { University of applied science }^{\circ} \\
\text { State examination (teacher) }^{\circ}\end{array}$ & $\begin{array}{l}18.29 \\
0.50 \\
0.34 \\
0.16\end{array}$ & $\begin{array}{l}18.25 \\
0.55^{* * *} \\
0.41^{* * *} \\
0.04^{* * *}\end{array}$ & $\begin{array}{l}18.32 \\
0.46 \\
0.36 \\
0.18\end{array}$ & $\begin{array}{l}18.05 \\
0.59^{* * *} \\
0.37 \\
0.05^{* * *}\end{array}$ & $\begin{array}{l}19.02 \\
0.54^{* * *} \\
0.40 \\
0.06^{* * *}\end{array}$ \\
\hline $\begin{array}{l}\text { Field of study } \\
\text { Languages and Cultural Studies }^{\circ}(\mathrm{R}) \\
\text { Economics, Law and Social Sciences } \\
\text { Math, Natural Sciences }^{\circ} \\
\text { Medicine }^{\circ} \\
\text { Agriculture }^{\circ} \\
\text { Engineering }^{\circ}\end{array}$ & $\begin{array}{l}0.25 \\
0.33 \\
0.17 \\
0.06 \\
0.02 \\
0.17\end{array}$ & $\begin{array}{l}0.19^{* * *} \\
0.35 \\
0.14^{* *} \\
0.09^{* * *} \\
0.03^{* *} \\
0.20^{* * *}\end{array}$ & $\begin{array}{l}0.25 \\
0.32 \\
0.17 \\
0.06 \\
0.02 \\
0.18\end{array}$ & $\begin{array}{l}0.20^{* * *} \\
0.35 \\
0.16 \\
0.08^{* * *} \\
0.03^{* * *} \\
0.19\end{array}$ & $\begin{array}{l}0.20^{* *} \\
0.35 \\
0.14 \\
0.08^{* *} \\
0.03^{* *} \\
0.20\end{array}$ \\
\hline $\begin{array}{l}\text { Socio-economic characteristics } \\
\text { Female }\end{array}$ & 0.51 & 0.51 & 0.52 & 0.49 & 0.49 \\
\hline Age & 27.54 & $26.94^{* * *}$ & 27.62 & $26.97^{* * *}$ & 27.34 \\
\hline $\begin{array}{l}\text { Single }^{\circ}(\mathrm{R}) \\
\text { Partner, but not married } \\
\text { Married }^{\circ}\end{array}$ & $\begin{array}{l}0.32 \\
0.55 \\
0.13\end{array}$ & $\begin{array}{l}0.35^{* *} \\
0.55 \\
0.10^{* * *}\end{array}$ & $\begin{array}{l}0.31 \\
0.55 \\
0.14\end{array}$ & $\begin{array}{l}0.36^{* * *} \\
0.54 \\
0.09^{* * *}\end{array}$ & $\begin{array}{l}0.32 \\
0.57 \\
0.12\end{array}$ \\
\hline Children $^{\circ}$ & 0.09 & $0.06^{* * *}$ & 0.10 & $0.06^{* * *}$ & $0.06^{* *}$ \\
\hline Vocational training $^{\circ}$ & 0.30 & $0.28^{*}$ & 0.31 & $0.27^{* * *}$ & 0.28 \\
\hline $\begin{array}{l}\text { Characteristics of the university state } \\
\text { GDP growth rate / German average } \\
\text { Unemployment rate / German average } \\
\text { Share of firms with > } 250 \text { employees / German average } \\
\text { Share of population in cities / German average } \\
\text { University state in East Germany }{ }^{\circ}\end{array}$ & $\begin{array}{l}0.94 \\
0.81 \\
12.21 \\
0.97 \\
0.15\end{array}$ & $\begin{array}{l}0.99^{* * *} \\
0.92^{* * *} \\
9.25^{* * *} \\
0.92 \\
0.28^{* * *}\end{array}$ & $\begin{array}{l}0.93 \\
0.80 \\
12.57 \\
0.99 \\
0.14\end{array}$ & $\begin{array}{l}0.99^{* * *} \\
0.91^{* * *} \\
9.33^{* * *} \\
0.91^{*} \\
0.28^{* * *}\end{array}$ & $\begin{array}{l}0.94 \\
0.82^{*} \\
11.53^{* * *} \\
0.96 \\
0.17\end{array}$ \\
\hline $\begin{array}{l}\text { Job search characteristics (first job) } \\
\text { Found job through friends or relatives } \\
\text { Found job through previous employment experience }^{\circ} \\
\text { Number of applications } \\
\text { Difficulty: Few jobs offered }{ }^{\circ} \\
\text { Difficulty: Salary expectation } \\
\text { Difficulty: Jobs too far away } \\
\text { Difficulty: Reconciliation of family and work }\end{array}$ & $\begin{array}{l}0.15 \\
0.42 \\
14.87 \\
0.33 \\
0.10 \\
0.17 \\
0.12\end{array}$ & $\begin{array}{l}0.15 \\
0.26^{* * *} \\
21.86^{* * *} \\
0.36^{* *} \\
0.14^{* * *} \\
0.14^{* * *} \\
0.13\end{array}$ & $\begin{array}{l}0.15 \\
0.43 \\
13.79\end{array}$ & $\begin{array}{l}0.16 \\
0.30^{* * *} \\
20.60^{* * *}\end{array}$ & $\begin{array}{l}0.16 \\
0.25^{* * *} \\
21.99^{* * *}\end{array}$ \\
\hline
\end{tabular}


Table 3: Summary statistics by migration taxonomy (continued)

\begin{tabular}{|c|c|c|c|c|c|}
\hline & \multicolumn{2}{|c|}{ University $\rightarrow$ First Job } & \multicolumn{3}{|c|}{$\begin{array}{c}\text { University } \rightarrow \text { Job } \\
\text { (five years after graduation) }\end{array}$} \\
\hline & Stayer & Migrant & Stayer & $\begin{array}{l}\text { Onward } \\
\text { migrant }\end{array}$ & $\begin{array}{l}\text { Return } \\
\text { migrant }\end{array}$ \\
\hline \multicolumn{6}{|l|}{ Characteristics of first job } \\
\hline Temporary contract $^{\circ}$ & & & 0.64 & $0.59^{* * *}$ & 0.60 \\
\hline Employed $^{\circ}(\mathrm{R})$ & & & 0.86 & 0.87 & 0.85 \\
\hline Self-employed ${ }^{\circ}$ & & & 0.14 & 0.13 & 0.14 \\
\hline Civil servant $^{\circ}$ & & & 0.01 & 0.01 & 0.01 \\
\hline Salary $(/ 1,000)$ & & & 0.01 & $0.01^{* * *}$ & $0.01^{* * *}$ \\
\hline Self-assessment: Adequate job level ${ }^{\circ}$ & & & 0.60 & $0.59^{*}$ & 0.55 \\
\hline \multicolumn{6}{|l|}{ Sector of first job } \\
\hline Agriculture, Forestry ${ }^{\circ}(\mathrm{R})$ & & & 0.02 & $0.02^{* *}$ & 0.02 \\
\hline Manufacturing $^{\circ}$ & & & 0.14 & $0.17^{*}$ & 0.15 \\
\hline Construction $^{\circ}$ & & & 0.06 & 0.07 & $0.08^{*}$ \\
\hline Trade $^{\circ}$ & & & 0.03 & $0.06^{* * *}$ & 0.05 \\
\hline Media $^{\circ}$ & & & 0.03 & 0.03 & 0.04 \\
\hline Telecommunication ${ }^{\circ}$ & & & 0.05 & 0.06 & 0.05 \\
\hline Banking $^{\circ}$ & & & 0.05 & $0.08^{* * *}$ & $0.10^{* *}$ \\
\hline Research $^{\circ}$ & & & 0.12 & $0.14^{* *}$ & 0.11 \\
\hline Public administration ${ }^{\circ}$ & & & 0.07 & 0.06 & 0.06 \\
\hline Education $^{\circ}$ & & & 0.21 & $0.09^{* * *}$ & $0.08^{* * *}$ \\
\hline Health care $^{\circ}$ & & & 0.14 & 0.13 & 0.14 \\
\hline Organizations $^{\circ}$ & & & 0.08 & 0.10 & 0.11 \\
\hline \multicolumn{6}{|l|}{ Reasons for changing the latest job } \\
\hline Job change: improve chances of advancement ${ }^{\circ}$ & & & 0.28 & $0.43^{* * *}$ & $0.51^{* * *}$ \\
\hline Job change: improve salary $^{\circ}$ & & & 0.30 & $0.45^{* * *}$ & $0.51^{* * *}$ \\
\hline Job change: lower distance from partner ${ }^{\circ}$ & & & 0.13 & $0.19^{* * *}$ & $0.45^{* * *}$ \\
\hline Job change: improve qualification matching ${ }^{\circ}$ & & & 0.21 & $0.30^{* * *}$ & $0.37^{* * *}$ \\
\hline
\end{tabular}

Notes: ${ }^{\circ}$ Dummy variable: $1=$ yes, $0=$ no. (R) Reference category. T-tests on group average comparison with 'Stayers' as comparison group.

Source: DZHW graduate survey, own computations.

\section{Empirical strategy}

For the estimation, a multinomial logit model similar to Faggian et al. (2007) is used. The basic idea is that among a range $J$ of alternatives - here the migration alternatives individuals choose the one which offers them the highest indirect utility, $V_{i j}$, where $i$ denotes the individual and $j$ the alternative. Indirect utility depends on alternative-invariant variables, $x_{i}$. Assuming a linear relationship and adding an error term, $V_{i j}$ is represented by the following equation

$$
V_{i j}=\boldsymbol{x}_{\boldsymbol{i}}^{\prime} \boldsymbol{\beta}_{\mathbf{j}}+\epsilon_{i j}
$$

$\boldsymbol{x}_{\boldsymbol{i}}^{\prime}$ is assumed to vary only across individuals, while the set of regression coefficients $\boldsymbol{\beta}_{\boldsymbol{j}}$, varies with alternatives $j$. The error term $\epsilon_{i j}$ is i.i.d. 
The observed variable $y_{i}$ indicates which alternative an individual has chosen. Thus for $k \in J, y_{i k}=1$ and $y_{i l}=0(l \neq k)$ if $V_{i k}=\max _{j}\left(V_{i j}\right)$. As the indirect utility contains the stochastic component $\epsilon_{i j}$, the choice of the alternative is probabilistic.

In the following, two cases are considered. First, migration for the first job comprises two alternatives: Individuals can stay in the university state for their first job ('Stayer', $j=0$ ) or they can migrate to another state, ('Migrant', $j=1$ ) with stayers as the reference category. The probability that a graduate chooses alternative $j=0,1$ can be estimated by applying a logit model (Wooldridge 2012) with

$$
\begin{aligned}
& P_{i 0}=P\left(y_{i}=0 \mid x_{i}\right)=\frac{1}{1+e^{x_{i}^{\prime} \beta_{1}}} \\
& P_{i 1}=P\left(y_{i}=1 \mid x_{i}\right)=\frac{e^{x_{i}^{\prime} \beta_{1}}}{1+e^{x_{i}^{\prime} \beta_{1}}}
\end{aligned}
$$

Second, the determinants of migration within the first five years after graduation are analysed. There are three alternatives which define the migration type: stayers $(j=0)$, onward migrants $(j=1)$ and return migrants $(j=2)$ (cf. Section 2.2). Note that there is no natural order implied. In the empirical model, these alternatives will constitute the three realizations of the dependent variable Migration type with the stayers representing again the reference category.

Applying a multinomial logit model ${ }^{11}$, the probability that individual $i$ chooses alternative $j$ is now

$$
\begin{aligned}
& P_{i 0}=P\left(y_{i}=0 \mid x_{i}\right)=\frac{1}{1+\sum_{j=1}^{2} e^{x_{i}^{\prime} \beta_{j}}} \\
& P_{i s}=P\left(y_{i}=s \mid x_{i}\right)=\frac{e^{x_{i}^{\prime} \beta_{s}}}{1+\sum_{j=1}^{2} e^{x_{i}^{\prime} \beta_{j}}} \quad s \neq 0
\end{aligned}
$$

The outcomes of the multinomial logit model reflect the likelihood of individual $i$ to choose one of the three alternatives as a function of a vector of control variables. Average marginal effects are provided for each model in order to analyse not only the statistical but also the economic magnitude of the effects.

\section{Results}

\subsection{Migration for the first job}

Table 4 reports the marginal effects from logit models for the migration choice between graduating from university and entering the labor market for the first job. The respective coefficients can be found in Table A.2 in the Appendix. Model 1 is estimated without job search characteristics (cf. Section 3) whereas in Model 2, they are added.

\footnotetext{
${ }^{11}$ Note, that the decision to migrate to a specific destination is not explicitly modelled. The interest lies in the factors that influence the probability of an individual to choose one or the other alternative. Also note, that there are no additional alternatives that could be added. For these reasons, the independence of irrelevant alternatives assumptions (IIA), which is a feature of the multinomial logit model, is less relevant in the context here.
} 
Previous migration was proven to be an important determinant of subsequent migration (Parey and Waldinger 2011). Table 4 shows that migration before or during the studies affects the likelihood to out-migrate after graduation in a positive and highly significant way. Graduates who have migrated to the university state are about 25 percentage points more likely to out-migrate after graduation. Similarly, the propensity to out-migrate after graduation is more than 10 percentage points higher for those who went abroad during their studies.

Table 4: Determinants of migration for the first job - Logit model, Marginal effects

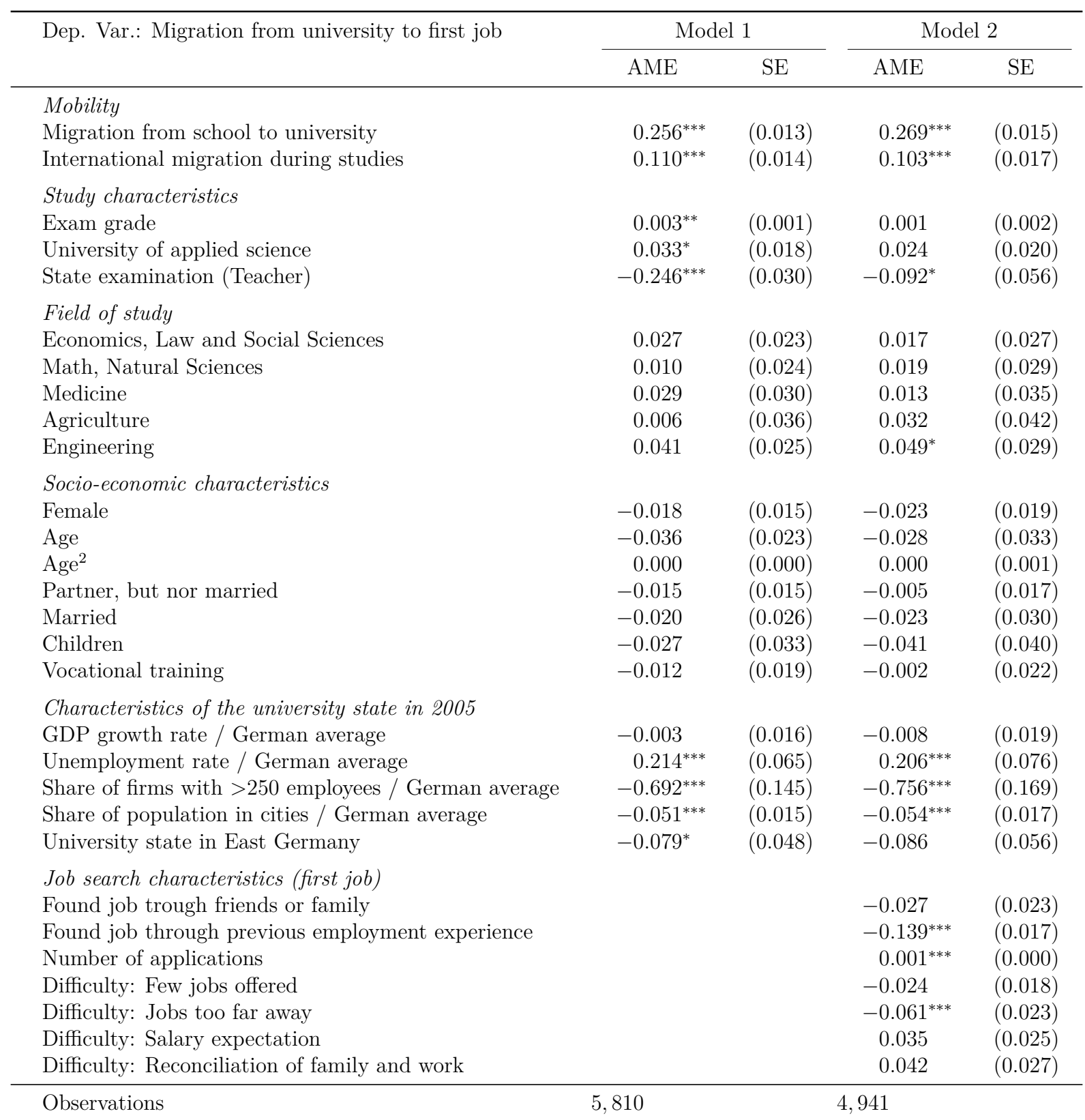

Notes: Average marginal effects (AME) reported. Robust standard errors in parentheses; ${ }^{* * *} \mathrm{p}<0.01,{ }^{* *}$ $\mathrm{p}<0.05,{ }^{*} \mathrm{p}<0.1$. The coefficients of the logit regression are displayed in Table A.2.

As to the degree type, contrary to the results of Busch and Weigert (2010), in the basic 
specification we find that students who graduated from a university of applied sciences are significantly more likely to leave the university region than graduates from universities. When including the job search controls, however, the marginal effect becomes insignificant. For the first job, we cannot confirm that graduates from universities of applied sciences are more oriented towards the regional labor market. On the contrary, graduates with a teachers' degree are nearly 25 percentage points less likely to leave the university state and almost 10 percentage points less likely when job search characteristics are controlled for. For the graduates' exam grade, we find a positive and significant effect on migration when job search characteristics are not included. ${ }^{12}$ Less able students are more likely to migrate after graduation - a result also found by Krabel and Flöther (2012). The study fields, however, do not affect graduates' likelihood to migrate for their first employment.

Interestingly, we do not find any significant effects with respect to socio-economic characteristics. However, our regional control variables, i.e. the university state's unemployment rate, its share of large firms and its share of the population living in cities, affect the migration probability in a statistically significant way. Intuitively, having graduated in a state with a relatively high unemployment rate increases the graduates' probability to out-migrate for work reasons. The smaller the share of inhabitants living in cities or the share of firms with more than 250 employees, the larger the likelihood that graduates leave the university state for their first job. A degree from an East German university does not play an important role.

With respect to the job search characteristics, we confirm the results of Krabel and Flöther (2012). Graduates who found their first job through previous employment experience are approximately 14 percentage points more likely to stay while the help of friends or relatives does not significantly correlate with the probability of out-migration. Graduates who consider adequate jobs to be too far away are, not surprisingly, less likely to migrate whereas, e.g., the salary expectation or work-family balance do not affect the migration decision significantly.

\subsection{Migration after the first job}

In the second part of our empirical analysis, we investigate the determinants of graduate migration in the longer run. As we observe graduates for the full period of the first five years after graduation, we can provide a more detailed picture of different migration patterns of German graduates.

The results from our multinomial logit model for the two migrant categories "onward migrants" and "return migrants" relative to "stayers" are presented in Table 5 (cf. Section 2.3). Again, we report the respective average marginal effects.

Let us, first, have a closer look at the variables that capture possible earlier migration experience. Having graduated in a state different from the school state makes it almost 15 percentage points more likely to be an onward migrant than to be a stayer (either because of moving back to the school state or because of moving to a third state). However, it makes a graduate about 6 percentage points less likely to be a return migrant, that is, to migrate again after graduation but later return to the university state. Graduates who have their first job in the state in which they went to school are significantly less likely to

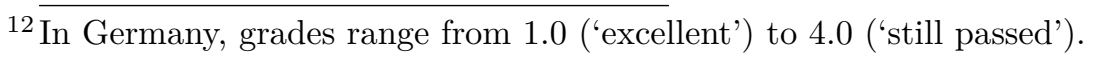


be an onward migrant and even less likely to be a return migrant. Again, they either stayed all the time there or decided to go back to their school state after graduation. Having been abroad during studies makes it 7 percentage points more likely to be an onward migrant but not to be a return migrant compared to being a stayer. Very intuitively, the probability of being both an onward and a return migrant increases with the number of jobs a graduate has within the first five years after graduation. This confirms the link between job changes and inter-state migration as observed in Section 2.

As to the study characteristics, we find that less able students are significantly more likely to be a return migrant but not to be an onward migrant. Having in mind the significantly higher probability of low-performing students to out-migrate for their first job, one may conclude that bad grades may force graduates to take a first job elsewhere. When having acquired some work experience, however, it may be easier to find a job in the former university region. Consistent with the results in Table 4 , teachers are more likely stay in the state in which they graduated. In the medium run, we can now confirm the results found in previous literature (see, e.g., Jaeger and Kopper 2014) that graduates from universities of applied sciences are more likely to stay in the university state than to be an onward migrant compared to graduates from universities. Again, the study fields do not have any significant effect for either migrant group.

In the medium-run, we now find that some socio-economic characteristics are significantly correlated with the migration type, with, however, relatively small effect sizes. Having children reduces the propensity to be any kind of migrant by 3 to 4 percentage points, presumably due to higher migration costs, i. e. the costs to adapt to a new environment. Being married or living in a partnership, on the contrary, makes graduates more likely to return to the university state.

Turning to the regional characteristics, we confirm our previous results, however, only for onward migrants but not for return migrants. Having graduated in a university state with a relatively high unemployment rate, a lower share of large firms and a lower share of inhabitants living in large cities makes it more likely to be an onward migrant. As return migrants are defined as migrants who out-migrate but later return to the university state, it seems reasonable that we do not find significant effects of regional characteristics for this group. Obviously, factors other than economic ones significantly contribute to their decision to return. Graduates from an East German university are more likely to stay in the university state or to return there.

Characteristics of the first job and the sector play hardly any role for the likelihood to migrate. 
Table 5: Determinants of migration for the last job - Multinomial logit model, Marginal effects

\begin{tabular}{|c|c|c|c|c|}
\hline \multirow{3}{*}{ Dep. Var.: Migration type } & \multicolumn{4}{|c|}{ Model 3} \\
\hline & \multicolumn{2}{|c|}{ Onward migrant } & \multicolumn{2}{|c|}{ Return migrant } \\
\hline & AME & $\mathrm{SE}$ & AME & $\mathrm{SE}$ \\
\hline Mobility & & & & \\
\hline Migration from school to university & $0.149^{* * *}$ & $(0.020)$ & $-0.062^{* * *}$ & $(0.014)$ \\
\hline International migration during studies & $0.076^{*}$ & $(0.016)$ & -0.006 & $(0.011)$ \\
\hline School state $=$ State of first job & $-0.220^{* * *}$ & $(0.016)$ & $-0.103^{* * *}$ & $(0.012)$ \\
\hline Number of jobs within five years after graduation & $0.025^{* * *}$ & $(0.006)$ & $0.036^{* * *}$ & $(0.003)$ \\
\hline $\begin{array}{l}\text { Study characteristics } \\
\text { Exam grade } \\
\text { University of applied science } \\
\text { State examination (Teacher) }\end{array}$ & $\begin{array}{l}-0.002 \\
-0.051^{* *} \\
-0.132^{* * *}\end{array}$ & $\begin{array}{l}(0.002) \\
(0.020) \\
(0.046)\end{array}$ & $\begin{array}{c}0.002^{* *} \\
0.013 \\
-0.026\end{array}$ & $\begin{array}{l}(0.001) \\
(0.013) \\
(0.030)\end{array}$ \\
\hline $\begin{array}{l}\text { Field of study } \\
\text { Economics, Law and Social Sciences } \\
\text { Math, Natural Sciences } \\
\text { Medicine } \\
\text { Agriculture } \\
\text { Engineering }\end{array}$ & $\begin{array}{r}0.007 \\
0.027 \\
0.056 \\
-0.023 \\
-0.003\end{array}$ & $\begin{array}{l}(0.028) \\
(0.029) \\
(0.042) \\
(0.047) \\
(0.033)\end{array}$ & $\begin{array}{r}-0.015 \\
-0.006 \\
0.025 \\
0.003 \\
-0.007\end{array}$ & $\begin{array}{c}(0.021) \\
(0.022) \\
(0.027) \\
(0.027) \\
(0.024)\end{array}$ \\
\hline $\begin{array}{l}\text { Socio-economic characteristics } \\
\text { Female } \\
\text { Age } \\
\text { Age }^{2} \\
\text { Partner, but nor married } \\
\text { Married } \\
\text { Children } \\
\text { Vocational training }\end{array}$ & $\begin{array}{l}-0.029 \\
-0.019 \\
0.000 \\
-0.025 \\
-0.019 \\
-0.043^{* *} \\
0.010\end{array}$ & $\begin{array}{l}(0.019) \\
(0.028) \\
(0.000) \\
(0.018) \\
(0.030) \\
(0.018) \\
(0.022)\end{array}$ & $\begin{array}{r}-0.011 \\
0.003 \\
-0.000 \\
0.020^{*} \\
0.036^{*} \\
-0.031^{* *} \\
-0.027^{*}\end{array}$ & $\begin{array}{l}(0.012) \\
(0.016) \\
(0.000) \\
(0.012) \\
(0.019) \\
(0.012) \\
(0.015)\end{array}$ \\
\hline $\begin{array}{l}\text { Characteristics of the university state in } 2005 \\
\text { GDP growth rate / German average } \\
\text { Unemployment rate / German average } \\
\text { Share of firms with > } 250 \text { employees / German average } \\
\text { Share of population in cities / German average } \\
\text { University state in East Germany }\end{array}$ & $\begin{array}{l}-0.019 \\
0.262^{* * *} \\
-0.591^{* * *} \\
-0.079^{* * *} \\
-0.111^{* *}\end{array}$ & $\begin{array}{l}(0.018) \\
(0.074) \\
(0.163) \\
(0.017) \\
(0.053)\end{array}$ & $\begin{array}{r}-0.002 \\
-0.037 \\
0.009 \\
0.008 \\
-0.007\end{array}$ & $\begin{array}{l}(0.012) \\
(0.048) \\
(0.106) \\
(0.011) \\
(0.035)\end{array}$ \\
\hline $\begin{array}{l}\text { Characteristics of first job } \\
\text { Temporary contract } \\
\text { Self-employed } \\
\text { Civil servant } \\
\text { Salary }(1,000) \\
\text { Self-assessment: Adequate job level }\end{array}$ & $\begin{array}{r}-0.027 \\
-0.006 \\
0.037 \\
0.003 \\
-0.027\end{array}$ & $\begin{array}{l}(0.019) \\
(0.025) \\
(0.102) \\
(0.011) \\
(0.017)\end{array}$ & $\begin{array}{r}-0.004 \\
-0.013 \\
-0.011 \\
0.006 \\
-0.002\end{array}$ & $\begin{array}{c}(0.012) \\
(0.018) \\
(0.057) \\
(0.007) \\
(0.011)\end{array}$ \\
\hline $\begin{array}{l}\text { Sector of first job } \\
\text { Manufacturing } \\
\text { Construction } \\
\text { Trade } \\
\text { Media } \\
\text { Telecommunication } \\
\text { Banking } \\
\text { Research } \\
\text { Public administration } \\
\text { Education } \\
\text { Health care } \\
\text { Organizations }\end{array}$ & $\begin{array}{l}-0.042 \\
-0.029 \\
-0.004 \\
-0.087 \\
-0.082 \\
-0.056 \\
-0.080 \\
-0.075 \\
-0.123^{* *} \\
-0.092^{*} \\
-0.083\end{array}$ & $\begin{array}{l}(0.049) \\
(0.052) \\
(0.056) \\
(0.061) \\
(0.058) \\
(0.053) \\
(0.052) \\
(0.063) \\
(0.062) \\
(0.053) \\
(0.051)\end{array}$ & $\begin{array}{r}0.020 \\
0.028 \\
0.028 \\
0.000 \\
0.005 \\
0.042 \\
-0.000 \\
0.009 \\
-0.004 \\
-0.002 \\
0.025\end{array}$ & $\begin{array}{l}(0.032) \\
(0.034) \\
(0.037) \\
(0.039) \\
(0.036) \\
(0.035) \\
(0.032) \\
(0.041) \\
(0.039) \\
(0.033) \\
(0.035)\end{array}$ \\
\hline
\end{tabular}

Notes: Reference category: Stayer. Average marginal effects (AME) reported. Robust standard errors in parentheses; ${ }^{* * *} \mathrm{p}<0.01,{ }^{* *} \mathrm{p}<0.05,{ }^{*} \mathrm{p}<0.1$. The coefficients of the multinomial logit regression are displayed in Table A.3. 
As an extension, we add variables to the regression in Table 5 which capture self-reported reasons for having taken the last job (see Table 6). While the effects of previous migration on subsequent migration remain virtually unchanged, additional insights into the reasons for a job change and their relation with the migration patterns can be gained. Changing a job in order to improve the salary makes it more likely that an individual is an onward migrant. Changing the job in order to move closer to one's partner (after having acquired some employment experience in another state), significantly contributes to the decision to return to the university state.

Table 6: Determinants of migration for the last job (reasons)- Multinomial logit model, Marginal effects

\begin{tabular}{|c|c|c|c|c|}
\hline \multirow{3}{*}{ Dep. Var.: Migration type } & \multicolumn{4}{|c|}{ Model 4} \\
\hline & \multicolumn{2}{|c|}{ Onward migrant } & \multicolumn{2}{|c|}{ Return migrant } \\
\hline & AME & $\mathrm{SE}$ & AME & SE \\
\hline \multicolumn{5}{|l|}{ Mobility } \\
\hline Migration from school to university & $0.147^{* * *}$ & $(0.020)$ & $-0.058^{* * *}$ & $(0.013)$ \\
\hline International migration during studies & $0.070^{* * *}$ & $(0.016)$ & -0.007 & $(0.011)$ \\
\hline School state $=$ State of first job & $-0.222^{* * *}$ & $(0.016)$ & $-0.094^{* * *}$ & $(0.011)$ \\
\hline Number of jobs within five years after graduation & $0.017^{* * *}$ & $(0.006)$ & $0.032^{* * *}$ & $(0.003)$ \\
\hline \multicolumn{5}{|l|}{ Reasons for changing the latest job } \\
\hline Job change: improve chances of advancement & -0.008 & $(0.025)$ & 0.012 & $(0.015)$ \\
\hline Job change: improve salary & $0.086^{* * *}$ & $(0.024)$ & -0.007 & $(0.015)$ \\
\hline Job change: lower spatial segregation from partner & -0.011 & $(0.019)$ & $0.100^{* * *}$ & $(0.011)$ \\
\hline Job change: improve qualification matching & 0.014 & $(0.021)$ & 0.008 & $(0.012)$ \\
\hline All additional controls (see Table 5) & $\checkmark$ & $\checkmark$ & $\checkmark$ & $\checkmark$ \\
\hline Observations & 4,740 & & & \\
\hline
\end{tabular}

Notes: See the notes of Table 5. The respective coefficients are displayed in Table A.4.

To conclude, our econometric analysis helps to understand in more detail how different medium-run migration patterns are affected by individual characteristics, university- and job-related aspects as well as state-level economic conditions. Many, but not all, of our results confirm those found in the literature. The results differ, however, in at least two respects: First, we find less evidence for the importance of socio-economic characteristics. One possible reason may be that most other studies use data aggregated on a (smaller) regional level in their analysis and thus focus more on "marginal" migration decisions. For the purpose of this study, i.e., given our interest in the fiscal considerations of states regarding their investment in higher education, an analysis at the state level is, however, appropriate. Second, we use several migration-specific control variables. They allow us to highlight in a differentiated way the role of previous migration and, in particular, how job changes and inter-state migration are related. 


\section{Conclusion}

With mobile graduates, public benefits of tertiary education may not accrue to the state which funded higher education. In this paper, we, first, descriptively analyze whether there is an imbalance of graduate migration between German states and, second, empirically study the determinants of the observed migration patterns. In particular, we are interested in whether there are states that gain from graduate migration and others that lose from it as well as in the underlying causes. For this, we not only study graduates' first employment after finishing university but also their subsequent employments within the first five years after graduation.

Our analysis provides a number of insightful results due to the migration-specific information available: First, roughly one out of two graduates on average stays in the university state within the first five years after graduation. From a policy perspective, this provides evidence that the state that paid for educating the high skilled at least partially benefits from this investment. However, second, graduate migration between German states is generally unbalanced. There is a number of states that gain (such as Hesse, Berlin and Hamburg) while others seem to be less attractive for graduates (e.g. Lower Saxony, Saxony and Thuringia). The most important determinants of the migration decision are previous migration, while the probability of staying is higher for graduates with closer ties to the university state (in particular when having attended school there). Additionally, graduate migration between German states strongly depends on the states' economic conditions.

Some comments about our analysis are in order. First, from our estimation results one would conclude that those German states with less favorable economic conditions should undertake efforts to improve their productivity which fosters employment possibilities and leads to wage increases for the high skilled. However, a state's economic conditions cannot be changed easily, at least not in the short-run. This considerably limits a state's options to develop strategies that serve to keep own graduates or even to attract graduates from other states. Second, there is evidence that the presence of a university in a region can generate knowledge spillovers (Audretsch et al. 2005). Often, a strong positive correlation between the presence of a university and the emergence of (innovative) firms nearby is found with positive effects on regional development (see, e.g., Audretsch et al. 2005, Baptista and Mendonça 2010, Fritsch and Aamoucke 2013). These spillover effects have to be "added" to our analysis in order to get the full picture as to the public costs and benefits of providing and financing higher education when graduates are mobile.

However, the positive effects from educating students may not completely remove the disincentives to publicly fund higher education. As the states are mostly responsible for higher education, unbalanced graduate migration between German states is likely to have consequences for fiscal and education policy (Gérard and Uebelmesser 2014). States that costly educate students but do not appropriately benefit from the returns of higher education afterwards (e.g. by taxes and positive externalities) may underinvest in education; and so may states which costlessly benefit from other states' investment via immigration of high-skilled workers. These inefficiencies may, in turn, justify correction mechanisms.

Still, migration of high skilled individuals produces clear benefits. Given different relative demand and supply among regions with respect to highly skilled graduates of various 
study fields, migration can help to better match qualifications and jobs. It is therefore not reasonable to develop strategies in order to reduce migration or decrease public contributions to higher education, respectively. It may be rather worthwhile to foster policies which keep up a state's incentives to provide high quality tertiary education in the presence of mobile graduates. One possible strategy may be to increase the financial responsibilities of the federal government and decrease that of the states. By abolishing the "cooperation ban" between the federal government and the states in 2014, a first step into this direction has been undertaken in Germany.

Germany can also learn something from other countries policy-wise. In Switzerland, e.g., cantons that do not have own universities contribute to the costs of higher education of their high-school graduates via inter-cantonal transfers (Schmidt 2008). Similarly, Denmark, Finland, Norway and Sweden have implemented compensatory transfers related to their citizens studying in one of the four other countries (The Nordic Council 2012). In the German context, there is good reason, however, to deviate in one important point if the implementation of such a system is contemplated: the transfer should not be required from the school state of a graduate but from the state(s) where the graduate will find employment.

Last but not least, the students themselves could be required to contribute more to their higher education in form of tuition fees. After an episode where some German states had charged moderate fees, tuition fees for regular students were abolished mostly for social concerns related to equality of chances. There are, however, policy instruments suitable to address these concerns in the form of income-contingent loans and graduate taxes, which shift the payment to the period after graduation and make it dependent on the graduate's income (Poutvaara 2004, 2008). A reform of the system of higher education could therefore aim at a larger financial involvement of these three parties - the graduates, the state(s) of their employment and the federal level - in order to reduce the disincentives identified above for the public provision of higher education in Germany. 


\section{References}

Audretsch, David B., Erik E. Lehmann, and Susanne Warning (2005). "University spillovers and new firm location". Research policy 34(7), pp. 1113-1122.

Baptista, Rui and Joana Mendonça (2010). "Proximity to knowledge sources and the location of knowledge-based start-ups". The Annals of Regional Science 45(1), pp. 5-29.

Busch, Oliver and Benjamin Weigert (2010). "Where have all the graduates gone? Internal cross-state migration of graduates in Germany 1984-2004". The Annals of Regional Science 44(3), pp. 559-572.

Del Rey, Elena (2001). "Economic integration and public provision of education". Empirica 28(2), pp. 203-218.

Dohmen, Dieter and René Krempkow (2014). "Die Entwicklung der Hochschulfinanzierung - von 2000 bis 2025”. Konrad-Adenauer-Stiftung e. V., Sankt Augustin/Berlin.

Faggian, Alessandra and Philip McCann (2009). "Human capital, graduate migration and innovation in British regions". Cambridge Journal of Economics 33(2), pp. 317-333.

Faggian, Alessandra, Philip McCann, and Stephen Sheppard (2007). "Some evidence that women are more mobile than men: gender differences in UK graduate migration behavior". Journal of Regional Science 47(3), pp. 517-539.

Falk, Susanne and Fabian Kratz (2009). "Regionale Mobilität von Hochschulabsolventen beim Berufseinstieg". Beiträge zur Hochschulforschung 31(3), pp. 52-67.

Fritsch, Michael and Ronney Aamoucke (2013). "Regional public research, higher education, and innovative start-ups: An empirical investigation". Small Business Economics 41(4), pp. 865-885.

Gérard, Marcel and Silke Uebelmesser (2014). "Financing higher education when students and graduates are internationally mobile". In: From mobility of students to mobility of the highly skilled: Implications for fiscal and economic policy. Ed. by Marcel Gérard and Silke Uebelmesser. CESifo Series. MIT Press: Cambr., MA. Chap. 6.

Gibson, John and Steven Stillman (2009). "Why do big firms pay higher wages? Evidence from an international database". The Review of Economics and Statistics 91(1), pp. 213218.

Glaeser, Edward L. and Matthew G. Resseger (2010). "The complementarity between cities and skills". Journal of Regional Science 50(1), pp. 221-244.

Grotheer, Michael, Sören Isleib, Nicolai Netz, and Kolja Briedis (2012). "Hochqualifiziert und gefragt. Ergebnisse der zweiten HIS-HF Absolventenbefragung des Jahrgangs 2005". (HIS: Forum Hochschule 14/2012). Hannover: HIS.

Haussen, Tina, Janna Heider, and Silke Uebelmesser (2014). "Wanderungsverhalten von Hochschulabsolventen". Thüringer Memo 5, Thüringer Ministerium für Wirtschaft, Arbeit und Technologie, Erfurt.

Jaeger, Angelika and Johannes Kopper (2014). "Third mission potential in higher education: measuring the regional focus of different types of HEIs". Review of Regional Research 34(2), pp. 95-118.

Justman, Moshe and Jacques-Francois Thisse (2000). "Local public funding of higher education when skilled labor is imperfectly mobile". International Tax and Public Finance 7(3), pp. 247-258.

Krabel, Stefan and Choni Flöther (2012). "Here today, gone tomorrow? Regional labour mobility of German university graduates". Regional Studies 48(10), pp. 1-19. 
Krieger, Tim and Thomas Lange (2010). "Education policy and tax competition with imperfect student and labor mobility". International Tax and Public Finance 17(6), pp. 587-606.

Lenz, Karl, Andrä Wolter, Claudia Reiche, Michaela Fuhrmann, Dana Frohwieser, Martin Otto, Robert Pelz, and Sindy Vodel (2010). "Studium und Berufseinstieg: Ergebnisse der ersten Sächsischen Absolventenstudie". Technical University of Dresden, Dresden.

Marinelli, Elisabetta (2013). "Sub-national graduate mobility and knowledge flows: An exploratory analysis of onward-and return-migrants in Italy". Regional Studies 47(10), pp. 1618-1633.

Parey, Matthias and Fabian Waldinger (2011). "Studying abroad and the effect on international labour market mobility: Evidence from the introduction of Erasmus". The Economic Journal 121(551), pp. 194-222.

Poutvaara, Panu (2004). "Educating Europe: should public education be financed with graduate taxes or income-contingent loans?" CESifo Economic Studies 50(4), pp. 663684.

- (2008). "Public and private education in an integrated Europe: Studying to migrate and teaching to stay?" The Scandinavian Journal of Economics 110(3), pp. 591-608.

Schmidt, Juana (2008). "Das Hochschulsystem der Schweiz Aufbau, Steuerung und Finanzierung der schweizerischen Hochschulen". Beiträge zur Hochschulforschung 2, pp. $114-147$.

The Nordic Council (2012). Agreement Concluded by Denmark, Finland, Iceland, Norway and Sweden on Admission to Higher Education (31.10.2012). URL: www.norden.org.

Troske, Kenneth R. (1999). "Evidence on the employer size-wage premium from workerestablishment matched data". Review of Economics and Statistics 81(1), pp. 15-26.

Venables, Anthony J. (2010). "Productivity in cities: self-selection and sorting". Journal of Economic Geography 11(2), pp. 241-251.

Venhorst, Viktor, Jouke Van Dijk, and Leo Van Wissen (2011). "An analysis of trends in spatial mobility of Dutch graduates". Spatial Economic Analysis 6(1), pp. 57-82.

Wooldridge, Jeffrey (2012). Introductory econometrics: A modern approach. Cengage Learning. 


\section{Appendix}

Table A.1: Summary statistics

\begin{tabular}{|c|c|c|c|c|}
\hline Variables & Mean & Std. dev. & Min & $\operatorname{Max}$ \\
\hline \multicolumn{5}{|l|}{ Mobility } \\
\hline Migration from university to the first job $(\mathrm{DV})^{\circ}$ & 0.35 & 0.48 & 0.00 & 1.00 \\
\hline \multicolumn{5}{|l|}{ Migration type (DV) } \\
\hline Stayer ${ }^{\circ}$ & 0.50 & 0.50 & 0.00 & 1.00 \\
\hline Onward Migrant ${ }^{\circ}$ & 0.41 & 0.49 & 0.00 & 1.00 \\
\hline Return migrant $^{\circ}$ & 0.09 & 0.27 & 0.00 & 1.00 \\
\hline Migration from school to university ${ }^{\circ}$ & 0.30 & 0.46 & 0.00 & 1.00 \\
\hline International migration during studies ${ }^{\circ}$ & 0.35 & 0.48 & 0.00 & 1.00 \\
\hline School state $=$ state of the first job ${ }^{\circ}$ & 0.61 & 0.49 & 0.00 & 1.00 \\
\hline Number of jobs within five years after graduation & 2.74 & 1.38 & 0.00 & 10.00 \\
\hline \multicolumn{5}{|l|}{ Study characteristics } \\
\hline Exam grade & 18.58 & 5.54 & 10.00 & 40.00 \\
\hline University $^{\circ}(\mathrm{R})$ & 0.52 & 0.50 & 0.00 & 1.00 \\
\hline University of applied science $^{\circ}$ & 0.36 & 0.48 & 0.00 & 1.00 \\
\hline State examination (teacher) ${ }^{\circ}$ & 0.12 & 0.32 & 0.00 & 1.00 \\
\hline \multicolumn{5}{|l|}{ Field of study } \\
\hline Languages and Cultural Studies $^{\circ}(\mathrm{R})$ & 0.23 & 0.42 & 0.00 & 1.00 \\
\hline Economics, Law and Social Sciences ${ }^{\circ}$ & 0.34 & 0.47 & 0.00 & 1.00 \\
\hline Math, Natural Sciences ${ }^{\circ}$ & 0.16 & 0.36 & 0.00 & 1.00 \\
\hline Medicine $^{\circ}$ & 0.07 & 0.25 & 0.00 & 1.00 \\
\hline Agriculture $^{\circ}$ & 0.02 & 0.15 & 0.00 & 1.00 \\
\hline Engineering ${ }^{\circ}$ & 0.18 & 0.38 & 0.00 & 1.00 \\
\hline \multicolumn{5}{|l|}{ Socio-economic characteristics } \\
\hline Gender $(1=$ female, $0=$ male $)$ & 0.51 & 0.50 & 0.00 & 1.00 \\
\hline Age & 27.31 & 3.44 & 22.00 & 59.00 \\
\hline $\mathrm{Age}^{2}$ & 757.84 & 223.61 & 484.00 & $3,481.00$ \\
\hline Single $^{\circ}(\mathrm{R})$ & 0.33 & 0.47 & 0.00 & 1.00 \\
\hline Partner, but not married ${ }^{\circ}$ & 0.54 & 0.50 & 0.00 & 1.00 \\
\hline Married $^{\circ}$ & 0.12 & 0.33 & 0.00 & 1.00 \\
\hline Children ${ }^{\circ}$ & 0.08 & 0.27 & 0.00 & 1.00 \\
\hline Vocational training $^{\circ}$ & 0.29 & 0.45 & 0.00 & 1.00 \\
\hline \multicolumn{5}{|l|}{ Characteristics of the university state in 2005} \\
\hline GDP growth rate / German average & 0.94 & 0.54 & 0.21 & 3.93 \\
\hline Unemployment rate / German average & 0.81 & 0.29 & 0.51 & 1.47 \\
\hline Share of firms with $>250$ employees / German average & 11.24 & 6.73 & 0.77 & 21.04 \\
\hline Share of population in cities / German average & 0.94 & 0.68 & 0.32 & 3.26 \\
\hline University state in East Germany $^{\circ}$ & 0.20 & 0.40 & 0.00 & 1.00 \\
\hline \multicolumn{5}{|l|}{ Job search characteristics (first job) } \\
\hline Found job through friends or relatives ${ }^{\circ}$ & 0.13 & 0.34 & 0.00 & 1.00 \\
\hline Found job through previous employment experience ${ }^{\circ}$ & 0.36 & 0.48 & 0.00 & 1.00 \\
\hline Number of applications & 18.68 & 29.29 & 0.00 & 500.00 \\
\hline Difficulty: Few jobs offered ${ }^{\circ}$ & 0.35 & 0.48 & 0.00 & 1.00 \\
\hline Difficulty: Salary expectation ${ }^{\circ}$ & 0.11 & 0.32 & 0.00 & 1.00 \\
\hline Difficulty: Jobs too far away ${ }^{\circ}$ & 0.16 & 0.36 & 0.00 & 1.00 \\
\hline Difficulty: Reconciliation of family and work ${ }^{\circ}$ & 0.12 & 0.33 & 0.00 & 1.00 \\
\hline
\end{tabular}


Table A.1: Summary statistics (continued)

\begin{tabular}{|c|c|c|c|c|}
\hline Variables & Mean & Std. dev. & Min & $\operatorname{Max}$ \\
\hline \multicolumn{5}{|l|}{ Characteristics of first job } \\
\hline Unlimited $^{\circ}(\mathrm{R})$ & 0.38 & 0.49 & 0.00 & 1.00 \\
\hline Temporary contract ${ }^{\circ}$ & 0.62 & 0.49 & 0.00 & 1.00 \\
\hline Employed ${ }^{\circ}(\mathrm{R})$ & 0.85 & 0.36 & 0.00 & 1.00 \\
\hline Self-employed ${ }^{\circ}$ & 0.14 & 0.35 & 0.00 & 1.00 \\
\hline Civil servant ${ }^{\circ}$ & 0.01 & 0.08 & 0.00 & 1.00 \\
\hline Salary $(/ 1,000)$ & 2.07 & 1.09 & 0.05 & 11.55 \\
\hline Self-assessment: Adequate job level ${ }^{\circ}$ & 0.59 & 0.49 & 0.00 & 1.00 \\
\hline \multicolumn{5}{|l|}{ Sector of first job } \\
\hline Agriculture, Forestry ${ }^{\circ}(\mathrm{R})$ & 0.02 & 0.14 & 0.00 & 1.00 \\
\hline Manufacturing ${ }^{\circ}$ & 0.14 & 0.35 & 0.00 & 1.00 \\
\hline Construction ${ }^{\circ}$ & 0.06 & 0.25 & 0.00 & 1.00 \\
\hline Trade $^{\circ}$ & 0.04 & 0.20 & 0.00 & 1.00 \\
\hline Media ${ }^{\circ}$ & 0.03 & 0.17 & 0.00 & 1.00 \\
\hline Telecommunication ${ }^{\circ}$ & 0.05 & 0.22 & 0.00 & 1.00 \\
\hline Banking ${ }^{\circ}$ & 0.07 & 0.25 & 0.00 & 1.00 \\
\hline Research ${ }^{\circ}$ & 0.12 & 0.33 & 0.00 & 1.00 \\
\hline Public administration ${ }^{\circ}$ & 0.07 & 0.25 & 0.00 & 1.00 \\
\hline Education $^{\circ}$ & 0.16 & 0.37 & 0.00 & 1.00 \\
\hline Health care ${ }^{\circ}$ & 0.13 & 0.34 & 0.00 & 1.00 \\
\hline Organizations $^{\circ}$ & 0.09 & 0.29 & 0.00 & 1.00 \\
\hline \multicolumn{5}{|l|}{ Reasons for changing the latest job } \\
\hline Job change: improve chances of advancement ${ }^{\circ}$ & 0.35 & 0.48 & 0.00 & 1.00 \\
\hline Job change: improve salary $^{\circ}$ & 0.37 & 0.48 & 0.00 & 1.00 \\
\hline Job change: lower distance from partner ${ }^{\circ}$ & 0.18 & 0.38 & 0.00 & 1.00 \\
\hline Job change: improve qualification matching ${ }^{\circ}$ & 0.26 & 0.44 & 0.00 & 1.00 \\
\hline
\end{tabular}

${ }^{\circ}$ Dummy variable: $1=$ yes, $0=$ no. (R) Reference category. 
Table A.2: Determinants of migration for the first job - Logit model, Coefficients

\begin{tabular}{|c|c|c|c|c|}
\hline \multirow[t]{2}{*}{ Dep. Var.: Migration from university to first job } & \multicolumn{2}{|c|}{ Model A1 } & \multicolumn{2}{|c|}{ Model A2 } \\
\hline & Coef. & $\mathrm{SE}$ & Coef. & $\mathrm{SE}$ \\
\hline \multicolumn{5}{|l|}{ Mobility } \\
\hline Migration from school to university & $1.386^{* * *}$ & $(0.083)$ & $1.374^{* * *}$ & $(0.090)$ \\
\hline International migration during studies & $0.599^{* * *}$ & $(0.080)$ & $0.527^{* * *}$ & $(0.086)$ \\
\hline School state in East Germany & 0.133 & $(0.143)$ & 0.111 & $(0.143)$ \\
\hline University state in East Germany & $-0.522^{*}$ & $(0.278)$ & $-0.518^{*}$ & $(0.306)$ \\
\hline $\begin{array}{l}\text { Study characteristics } \\
\text { Exam grade } \\
\text { University of applied science } \\
\text { State examination (Teacher) }\end{array}$ & $\begin{array}{c}0.017^{* *} \\
0.179^{*} \\
-1.328^{* * *}\end{array}$ & $\begin{array}{l}(0.007) \\
(0.095) \\
(0.165)\end{array}$ & $\begin{array}{c}0.007 \\
0.119 \\
-0.472^{*}\end{array}$ & $\begin{array}{r}(0.008) \\
(0.103) \\
(0.287)\end{array}$ \\
\hline $\begin{array}{l}\text { Field of study } \\
\text { Economics, Law and Social Sciences } \\
\text { Math, Natural Sciences } \\
\text { Medicine } \\
\text { Agriculture } \\
\text { Engineering }\end{array}$ & $\begin{array}{l}0.146 \\
0.052 \\
0.158 \\
0.035 \\
0.218\end{array}$ & $\begin{array}{l}(0.124) \\
(0.130) \\
(0.165) \\
(0.195) \\
(0.136)\end{array}$ & $\begin{array}{l}0.084 \\
0.094 \\
0.068 \\
0.168 \\
0.248^{*}\end{array}$ & $\begin{array}{l}(0.138) \\
(0.150) \\
(0.178) \\
(0.215) \\
(0.148)\end{array}$ \\
\hline $\begin{array}{l}\text { Socio-economic characteristics } \\
\text { Female } \\
\text { Age } \\
\text { Age }^{2} \\
\text { Partner, but nor married } \\
\text { Married } \\
\text { Children } \\
\text { Vocational training }\end{array}$ & $\begin{array}{r}-0.099 \\
-0.188 \\
0.002 \\
-0.081 \\
-0.112 \\
-0.154 \\
-0.069\end{array}$ & $\begin{array}{l}(0.084) \\
(0.123) \\
(0.002) \\
(0.082) \\
(0.144) \\
(0.179) \\
(0.103)\end{array}$ & $\begin{array}{r}-0.119 \\
-0.134 \\
0.001 \\
-0.025 \\
-0.120 \\
-0.210 \\
-0.013\end{array}$ & $\begin{array}{l}(0.095) \\
(0.170) \\
(0.003) \\
(0.089) \\
(0.155) \\
(0.203) \\
(0.110)\end{array}$ \\
\hline $\begin{array}{l}\text { Characteristics of the university state in } 2005 \\
\text { GDP growth rate / German average } \\
\text { Unemployment rate / German average } \\
\text { Share of firms with > } 250 \text { employees / German average } \\
\text { Share of population in cities / German average }\end{array}$ & $\begin{array}{r}-0.014 \\
1.149^{* * *} \\
-0.037^{* * *} \\
-0.277^{* * *}\end{array}$ & $\begin{array}{l}(0.089) \\
(0.357) \\
(0.008) \\
(0.081)\end{array}$ & $\begin{array}{c}0.040 \\
1.044^{* * *} \\
-0.038^{* * *} \\
-0.276^{* * *}\end{array}$ & $\begin{array}{r}(0.097) \\
(0.393) \\
(0.009) \\
(0.088)\end{array}$ \\
\hline $\begin{array}{l}\text { Job search characteristics (first job) } \\
\text { Found job trough friends or relatives } \\
\text { Found job through previous employment experience } \\
\text { Number of applications } \\
\text { Difficulty: Few jobs offered } \\
\text { Difficulty: Salary expectation } \\
\text { Difficulty: Jobs too far away } \\
\text { Difficulty: Reconciliation of family and work }\end{array}$ & & & $\begin{array}{c}-0.139 \\
-0.712^{* * *} \\
0.005^{* * *} \\
-0.123 \\
0.182 \\
-0.312^{* * *} \\
0.215\end{array}$ & $\begin{array}{r}(0.117) \\
(0.090) \\
(0.002) \\
(0.090) \\
(0.125) \\
(0.117) \\
(0.137)\end{array}$ \\
\hline Constant & 1.942 & $(1.914)$ & 1.776 & $(2.577)$ \\
\hline Observations & 810 & & 941 & \\
\hline
\end{tabular}

Notes: Robust standard errors in parentheses. ${ }^{* * *} \mathrm{p}<0.01,{ }^{* *} \mathrm{p}<0.05,{ }^{*} \mathrm{p}<0.1$. 
Table A.3: Determinants of migration for the last job - Multinomial logit model, Coefficients

\begin{tabular}{|c|c|c|c|c|}
\hline \multirow{3}{*}{ Dep. Var.: Migration type } & \multicolumn{4}{|c|}{ Model A3 } \\
\hline & \multicolumn{2}{|c|}{ Onward migrant } & \multicolumn{2}{|c|}{ Return migrant } \\
\hline & Coef. & SE & Coef. & SE \\
\hline Mobility & & & & \\
\hline Migration from school to university & $0.748^{* * *}$ & $(0.129)$ & $-0.386^{*}$ & $(0.210)$ \\
\hline International migration during studies & $0.476^{* * *}$ & $(0.099)$ & 0.195 & $(0.160)$ \\
\hline School state $=$ State of first job & $-1.857^{* * *}$ & $(0.106)$ & $-2.451^{* * *}$ & $(0.176)$ \\
\hline Number of jobs within five years after graduation & $0.308^{* * *}$ & $(0.043)$ & $0.664^{* * *}$ & $(0.051)$ \\
\hline $\begin{array}{l}\text { Study characteristics } \\
\text { Exam grade } \\
\text { University of applied science } \\
\text { State examination (Teacher) }\end{array}$ & $\begin{array}{l}-0.003 \\
-0.289^{* *} \\
-0.977^{* * *}\end{array}$ & $\begin{array}{l}(0.010) \\
(0.125) \\
(0.277)\end{array}$ & $\begin{array}{c}0.027^{* *} \\
-0.002 \\
-0.917^{* *}\end{array}$ & $\begin{array}{l}(0.014) \\
(0.181) \\
(0.427)\end{array}$ \\
\hline $\begin{array}{l}\text { Field of study } \\
\text { Economics, Law and Social Sciences } \\
\text { Math, Natural Sciences } \\
\text { Medicine } \\
\text { Agriculture } \\
\text { Engineering }\end{array}$ & $\begin{array}{r}-0.014 \\
0.156 \\
0.471^{*} \\
-0.144 \\
-0.045\end{array}$ & $\begin{array}{l}(0.171) \\
(0.173) \\
(0.253) \\
(0.308) \\
(0.194)\end{array}$ & $\begin{array}{r}-0.208 \\
0.017 \\
0.608 \\
-0.045 \\
-0.113\end{array}$ & $\begin{array}{l}(0.303) \\
(0.309) \\
(0.378) \\
(0.425) \\
(0.333)\end{array}$ \\
\hline $\begin{array}{l}\text { Socio-economic characteristics } \\
\text { Female } \\
\text { Age } \\
\text { Age }^{2} \\
\text { Partner, but nor married } \\
\text { Married } \\
\text { Children } \\
\text { Vocational training }\end{array}$ & $\begin{array}{l}-0.236^{* *} \\
-0.119 \\
0.001 \\
-0.087 \\
0.011 \\
-0.404^{* * *} \\
-0.040\end{array}$ & $\begin{array}{l}(0.116) \\
(0.165) \\
(0.003) \\
(0.108) \\
(0.178) \\
(0.110) \\
(0.133)\end{array}$ & $\begin{aligned}- & 0.279 \\
- & 0.035 \\
& 0.000 \\
& 0.220 \\
& 0.478^{*} \\
- & 0.649^{* * *} \\
- & 0.383^{*}\end{aligned}$ & $\begin{array}{l}(0.177) \\
(0.212) \\
(0.003) \\
(0.169) \\
(0.256) \\
(0.170) \\
(0.211)\end{array}$ \\
\hline $\begin{array}{l}\text { Characteristics of the university state in } 2005 \\
\text { GDP growth rate / German average } \\
\text { Unemployment rate / German average } \\
\text { Share of firms with > } 250 \text { employees / German average } \\
\text { Share of population in cities / German average } \\
\text { University state in East Germany }\end{array}$ & $\begin{aligned}- & 0.133 \\
& 1.593^{* * *} \\
- & 3.879^{* * *} \\
- & 0.496^{* * *} \\
- & 0.767^{* *}\end{aligned}$ & $\begin{array}{l}(0.114) \\
(0.461) \\
(0.998) \\
(0.110) \\
(0.330)\end{array}$ & $\begin{array}{r}-0.099 \\
0.444 \\
-2.157 \\
-0.189 \\
-0.547\end{array}$ & $\begin{array}{l}(0.176) \\
(0.697) \\
(1.518) \\
(0.161) \\
(0.503)\end{array}$ \\
\hline $\begin{array}{l}\text { Characteristics of first job } \\
\text { Temporary contract } \\
\text { Self-employed } \\
\text { Civil servant } \\
\text { Salary }(1,000) \\
\text { Self-assessment: Adequate job level }\end{array}$ & $\begin{array}{c}-0.197^{*} \\
-0.086 \\
0.200 \\
0.047 \\
-0.186^{*}\end{array}$ & $\begin{array}{l}(0.115) \\
(0.157) \\
(0.591) \\
(0.062) \\
(0.102)\end{array}$ & $\begin{array}{r}-0.171 \\
-0.218 \\
-0.034 \\
0.112 \\
-0.134\end{array}$ & $\begin{array}{l}(0.171) \\
(0.254) \\
(0.749) \\
(0.103) \\
(0.158)\end{array}$ \\
\hline $\begin{array}{l}\text { Sector of first job } \\
\text { Manufacturing } \\
\text { Construction } \\
\text { Trade } \\
\text { Media } \\
\text { Telecommunication } \\
\text { Banking } \\
\text { Research } \\
\text { Public administration } \\
\text { Education } \\
\text { Health care } \\
\text { Organizations }\end{array}$ & $\begin{array}{c}-0.199 \\
-0.084 \\
0.084 \\
-0.577 \\
-0.525 \\
-0.207 \\
-0.529 \\
-0.458 \\
-0.826^{* *} \\
-0.617^{*} \\
-0.455\end{array}$ & $\begin{array}{l}(0.302) \\
(0.316) \\
(0.340) \\
(0.372) \\
(0.358) \\
(0.328) \\
(0.324) \\
(0.388) \\
(0.381) \\
(0.332) \\
(0.319)\end{array}$ & $\begin{array}{r}0.149 \\
0.328 \\
0.421 \\
-0.335 \\
-0.248 \\
0.438 \\
-0.311 \\
-0.144 \\
-0.531 \\
-0.390 \\
0.060\end{array}$ & $\begin{array}{l}(0.460) \\
(0.485) \\
(0.530) \\
(0.561) \\
(0.527) \\
(0.496) \\
(0.475) \\
(0.588) \\
(0.566) \\
(0.484) \\
(0.509)\end{array}$ \\
\hline Constant & 3.417 & $(2.571)$ & -1.194 & $(3.438)$ \\
\hline
\end{tabular}

Notes: Reference category: Stayer. Robust standard errors in parentheses; ${ }^{* * *} \mathrm{p}<0.01,{ }^{* *} \mathrm{p}<0.05,{ }^{*}$ $\mathrm{p}<0.1$. 
Table A.4: Determinants of migration for the last job (reasons) - Multinomial logit model, Coefficients

\begin{tabular}{|c|c|c|c|c|}
\hline \multirow{3}{*}{ Dep. Var.: Migration type } & \multicolumn{4}{|c|}{ Model A4 } \\
\hline & \multicolumn{2}{|c|}{ Onward migrant } & \multicolumn{2}{|c|}{ Return migrant } \\
\hline & Coef. & SE & Coef. & SE \\
\hline \multicolumn{5}{|l|}{ Mobility } \\
\hline Migration from school to university & $0.755^{* * *}$ & $(0.133)$ & -0.355 & $(0.217)$ \\
\hline International migration during studies & $0.448^{* * *}$ & $(0.100)$ & 0.177 & $(0.161)$ \\
\hline School state $=$ State of first job & $-1.889^{* * *}$ & $(0.110)$ & $-2.457^{* * *}$ & $(0.183)$ \\
\hline Number of jobs within five years after graduation & $0.245^{* * *}$ & $(0.043)$ & $0.596^{* * *}$ & $(0.054)$ \\
\hline \multicolumn{5}{|l|}{ Reasons for changing the latest job } \\
\hline Job change: improve chances of advancement & -0.003 & $(0.157)$ & 0.172 & $(0.226)$ \\
\hline Job change: improve salary & $0.549^{* * *}$ & $(0.152)$ & 0.229 & $(0.231)$ \\
\hline Job change: lower spatial segregation from partner & $0.332^{* * *}$ & $(0.125)$ & $1.594^{* * *}$ & $(0.170)$ \\
\hline Job change: improve qualification matching & 0.126 & $(0.133)$ & 0.188 & $(0.190)$ \\
\hline All additional controls (see Table 5) & $\checkmark$ & $\checkmark$ & $\checkmark$ & $\checkmark$ \\
\hline Observations & 4,740 & & & \\
\hline
\end{tabular}

Notes: Reference category: Stayer. Robust standard errors in parentheses; ${ }^{* * *} \mathrm{p}<0.01,{ }^{* *} \mathrm{p}<0.05,{ }^{*}$ $\mathrm{p}<0.1$. 